\title{
Gut
}

\section{Natural history of chronic hepatitis B virus infection in West Africa: a longitudinal population-based study from The Gambia}

\begin{tabular}{|c|c|}
\hline Journal: & Gut \\
\hline Manuscript ID: & gutjnl-2015-309892.R1 \\
\hline Article Type: & Original Article \\
\hline Date Submitted by the Author: & $\mathrm{n} / \mathrm{a}$ \\
\hline Complete List of Authors: & $\begin{array}{l}\text { Shimakawa, Yusuke; London School of Hygiene and Tropical Medicine, } \\
\text { Faculty of Epidemiology and Population Health } \\
\text { Lemoine, Maud; Imperial College London, ; MRC Unit, The Gambia, } \\
\text { Njai, Harr Freeya; MRC Unit, The Gambia, } \\
\text { Bottomley, Christian; London School of Hygiene and Tropical Medicine, } \\
\text { Faculty of Epidemiology and Population Health } \\
\text { Ndow, Gibril; MRC Unit, The Gambia, ; IARC, The Gambia Hepatitis } \\
\text { Intervention Study } \\
\text { Goldin, Robert; Imperial College London, Department of Histopathology } \\
\text { Jatta, Abdoulie; MRC Unit, The Gambia, } \\
\text { Jeng-Barry, Adam; MRC Unit, The Gambia, } \\
\text { Wegmuller, Rita; MRC International Nutrition Group, MRC Keneba } \\
\text { Moore, Sophie; London School of Hygiene and Tropical Medicine, Faculty of } \\
\text { Epidemiology and Population Health; MRC International Nutrition Group, } \\
\text { MRC Keneba } \\
\text { Baldeh, Ignatius; Ministry of Health and Social Welfare, } \\
\text { Taal, Makie; Ministry of Health and Social Welfare, } \\
\text { D'Alessandro, Umberto; MRC Unit, The Gambia, ; London School of } \\
\text { Hygiene and Tropical Medicine, Faculty of Epidemiology and Population } \\
\text { Health } \\
\text { Whittle, Hilton; London School of Hygiene and Tropical Medicine, Faculty of } \\
\text { Infectious and Tropical Diseases } \\
\text { Njie, Ramou; MRC Unit, The Gambia, ; IARC, The Gambia Hepatitis } \\
\text { Intervention Study } \\
\text { Thursz, Mark; Imperial College, Department of Academic Medicine } \\
\text { Mendy, Maimuna; IARC, }\end{array}$ \\
\hline Keywords: & HEPATITIS B, EPIDEMIOLOGY, HEPATOCELLULAR CARCINOMA \\
\hline
\end{tabular}

\section{SCHOLARONE ${ }^{\text {m }}$ \\ Manuscripts}




\section{Title}

Natural history of chronic hepatitis B virus infection in West Africa: a longitudinal population-based study from The Gambia

\section{Short Title}

Natural history of chronic hepatitis B in West Africa

\section{Authors}

Yusuke Shimakawa, PhD,${ }^{1,2,3,{ }^{*}}$ Maud Lemoine, $\mathrm{PhD},{ }^{1,4,{ }^{*}}$ Harr Freeya Njai, $\mathrm{PhD},{ }^{1}$ Christian Bottomley, PhD,${ }^{2}$ Gibril Ndow, MD, ${ }^{1,5}$ Robert D Goldin, MD, ${ }^{4}$ Abdoulie Jatta, ${ }^{1}$ Adam JengBarry, ${ }^{1}$ Rita Wegmuller, PhD,${ }^{6}$ Sophie Moore, PhD, ${ }^{2,6}$ Ignatius Baldeh, MSc, ${ }^{7}$ Makie Taal, PhD, ${ }^{7}$ Umberto D'Alessandro, PhD,${ }^{1,2}$ Hilton Whittle, FMedSci, ${ }^{8}$ Ramou Njie, PhD, ${ }^{1,5}$ Mark Thursz, MD, ${ }^{4}$ Maimuna Mendy, $\mathrm{PhD}^{9}$

* Equally contributed 
${ }^{1}$ Medical Research Council (MRC) Unit, The Gambia. Banjul, The Gambia.

${ }^{2}$ Faculty of Epidemiology and Population Health, London School of Hygiene and Tropical Medicine. London, UK.

${ }^{3}$ Unité d'Épidémiologie des Maladies Émergentes, Institut Pasteur. Paris, France

${ }^{4}$ Department of Hepatology, Imperial College London. London, UK.

${ }^{5}$ The Gambia Hepatitis Intervention Study, IARC, c/o MRC Unit, The Gambia. Banjul, The Gambia.

${ }^{6}$ MRC International Nutrition Group, MRC Keneba. West Kiang, The Gambia.

${ }^{7}$ Ministry of Health and Social Welfare. Banjul, The Gambia.

${ }^{8}$ Faculty of Infectious and Tropical Diseases, London School of Hygiene and Tropical Medicine. London, UK.

${ }^{9}$ International Agency for Research on Cancer (IARC). Lyon, France. 


\section{Correspondence}

Prof Mark Thursz

Department of Hepatology, Imperial College London, Norfolk Place, London, W2 1NY, UK

Email: m.thursz@imperial.ac.uk

Phone +44-(0)2033121903. Fax +44-(0)2077069161.

\section{Keywords}

Hepatitis B; natural history; infectious disease transmission, vertical; Africa

Word Count (excluding title page, abstract, references, figures and tables)

4,000 words 


\begin{abstract}
Abbreviations
\end{abstract}
ALT

APRI

AST

EASL

EIA

EPI

ESLD

GAVI

$\mathrm{HBeAg}$

HBsAg

HBV

HCC
Alanine transaminase

Aspartate transaminase (AST)-to-Platelet Ratio Index

Aspartate transaminase

European Association for the Study of the Liver

Enzyme immunoassay

Expanded Program on Immunization

End-stage liver disease

Global Alliance for Vaccines and Immunization

Hepatitis B e antigen

Hepatitis B surface antigen

Hepatitis B virus

Hepatocellular carcinoma 
4

5

HCV Hepatitis C virus

HDV Hepatitis D virus

IARC

International Agency for Research on Cancer

MRC

Medical Research Council

OR

Odds ratio

PROLIFICA Prevention of Liver Fibrosis and Cancer in Africa

SSA

Sub-Saharan Africa

WHO

World Health Organization 
Abstract

Background

The natural history of chronic hepatitis B virus (HBV) infection in sub-Saharan Africa is unknown. Data is required to inform WHO guidelines which are currently based on studies in Europe and Asia.

Methods

Between 1974 and 2008, sero-surveys were repeated in two Gambian villages, and an open cohort of treatment-naïve chronic HBV carriers was recruited. Participants were followed to estimate the rates of hepatitis $\mathrm{B}$ e ( $\mathrm{HBeAg})$ and surface antigen ( $\mathrm{HBsAg}$ ) clearance and incidence of hepatocellular carcinoma (HCC). In 2012-2013, a comprehensive liver assessment was conducted to estimate the prevalence of severe liver disease.

Results

405 chronic carriers (95\% genotype E), recruited at a median age of 10.8 years, were followed for a median length of 28.4 years. Annually, 7.4\% (95\% CI: 6.3-8.8\%) cleared $\mathrm{HBeAg}$ and $1.0 \%(0.8-1.2 \%)$ cleared HBsAg. The incidence of HCC was $55.5 / 100,000$ carrier-years $(95 \%$ 
CI: 24.9-123.5). In the 2012-2013 survey ( $n=301)$, 5.5\% (95\% CI: 3.4-9.0\%) had significant liver fibrosis. HBV genotype A (versus E), chronic aflatoxin B1 exposure, and an HBsAgpositive mother, a proxy for mother-to-infant transmission, were risk factors for liver fibrosis. A small proportion (16.0\%) of chronic carriers were infected via mother-to-infant transmission, however, this population represented a large proportion $(63.0 \%)$ of the cases requiring antiviral therapy.

\section{Conclusions}

The incidence of HCC amongst chronic HBV carriers in West Africa was higher than that in Europe but lower than rates in East Asia. High risk of severe liver disease amongst the few who are infected by their mothers underlines the importance of interrupting perinatal transmission in sub-Saharan Africa.

\section{Summary Box}

What is already known about this subject?

- Chronic hepatitis B virus infection is a common cause of liver disease in sub-Saharan Africa. 
- Although the WHO recently published its first HBV treatment guidelines with a main focus on resource-limited countries, their recommendations are based on Western and Asian studies, since there have been no natural history data from sub-Saharan Africa.

- Mother-to-infant transmission is a risk factor for chronic HBV infection, however, it is unclear whether this mode of transmission further increases the risk of severe liver disease in chronic carriers.

What are the new findings?

- The incidence rate of hepatocellular carcinoma (HCC) in treatment-naïve male chronic HBV carriers in The Gambia was higher than Europe but lower than in East Asia.

- Mother-to-infant transmission was a risk factor for persistent viral replication, elevated transaminase, significant fibrosis and HCC.

- The majority (63.0\%) of cases requiring antiviral therapy were attributable to maternal transmission.

- Among chronic HBV carriers, genotype A (versus E) and chronic exposure to aflatoxin B1 were associated with an elevated risk of significant liver fibrosis.

How might it impact on clinical practice in foreseeable future?

- The disproportionate risk of severe liver disease amongst people who acquired HBV from their mothers emphasizes the importance of interrupting perinatal transmission in sub-Saharan Africa. 


\section{INTRODUCTION}

In sub-Saharan Africa (SSA) chronic hepatitis B virus (HBV) infection is a major public health problem, which causes an estimated 61,000 deaths due to cirrhosis or hepatocellular carcinoma (HCC) each year [1]. Before the introduction of hepatitis B vaccine, $>70 \%$ of African children were exposed to HBV at birth or during childhood and $10-20 \%$ became chronic HBV carriers [2]. Currently, all African countries have integrated hepatitis B vaccine into their Expanded Program on Immunization (EPI).

Despite its efficacy in preventing chronic HBV infection, vaccination has several limitations as a control strategy. First, a large number of people who were infected prior to the vaccination programs are left with chronic HBV infection [3]. Second, hepatitis B vaccine does not always prevent mother-to-infant transmission [4], especially when the vaccine is not given at birth [5]. Though this mode of transmission is less frequent than horizontal transmission in SSA [6], the risk of HCC may be higher in vertically-transmitted chronic infections [7-9].

To overcome these limitations, antiviral therapy can be used to prevent HBV-related disease in cases of chronic HBV infection and also to prevent vertical HBV transmission. In March 2015, the World Health Organization (WHO) issued its first guidelines on chronic HBV infection to improve access to antiviral therapy in low- and middle-income countries. However, their recommendations are based on the findings from Asia, Europe and North America, since there have been no natural history data from SSA [3]. Understanding the natural history of chronic HBV infection is essential to inform decisions about who to treat and when to treat [3]. 
The UK Medical Research Council (MRC), the International Agency for Research on Cancer (IARC/WHO) and the Gambia Government have been supporting studies on HBV infection in The Gambia since the 1980's, and have established a population-based open cohort of treatment-naïve chronic HBV carriers. We used this cohort to describe the natural history of chronic HBV infection: i) the sero-clearance rates of hepatitis B e antigen (HBeAg) and surface antigen (HBsAg); ii) the incidence of HCC, end-stage liver disease (ESLD) and allcause mortality; iii) longitudinal changes in serum HBV DNA and alanine transaminase (ALT) levels; and iv) the prevalence of significant liver fibrosis and chronic liver disease requiring antiviral therapy according to the European Association for the Study of the Liver (EASL) [10] or the WHO guidelines [3]. We also estimated the HBV-related disease burden attributable to the mother-to-infant transmission in SSA by examining the associations between these outcomes and maternal HBsAg, a proxy for mother-to-infant HBV transmission [8].

\section{METHODS}

\section{Participants}

The cohort of chronic HBV carriers was recruited from Keneba and Manduar, two neighboring villages in West Kiang District. They are typical of many African rural communities where Mandinka and Jola people live in mud or lath-and-plaster houses roofed with thatch or corrugated iron with subsistence agriculture [11]. Primary health care has been available free of charge at the MRC Keneba Clinic. Baseline HBV sero-surveys were undertaken in 1974 and in 1980. In the first survey the entire population was surveyed $(n=1,317)$ and $13.2 \%$ were found to carry HBsAg [11] while the second survey was limited to 
children aged $<15$ years and their mothers $(n=802)$ [12]. Following the third sero-survey in 1984 [13], all non-immune children in Keneba/Manduar were invited to participate in an HBV vaccine trial [14]. Hepatitis B vaccination was introduced in the EPI in 1990 with a vaccine schedule starting at birth. Hepatitis B immunoglobulin has been unavailable. Between 1985 and 2008, sero-surveys to measure the vaccine efficacy were repeated every 4-5 years [4,14-17]. In parallel, those who had been tested HBsAg-positive were followed for HBV sero-markers in 1985, 1989, 1992, 1993, 1998, 2003, and 2008 (supplementary table 1). Survey participation was $92-100 \%$ and $50-85 \%$ in those aged $0-9$ and $10-19$ years, respectively [12-15].

\section{Liver assessment in 2012-2013}

Following community approval, people with chronic HBV infection in the cohort were invited to a liver assessment as part of the PROLIFICA (Prevention of Liver Fibrosis and Cancer in Africa) project [18]. Chronic infection was defined as serum HBsAg positivity at two visits at least six months apart. In individuals aged $\geq 13$ years, HBsAg positivity at only one visit was considered as chronic infection because, in the pre-vaccination era, $90 \%$ of children in Keneba/Manduar acquired the infection by the age of 13 years and new infections were uncommon beyond this age [13]. After written informed consent, participants, who had fasted overnight, underwent a standardized clinical examination that involved blood collection, abdominal ultrasound and liver stiffness measurement using transient elastography (Fibroscan, Echosens, France). Those with serum HBV DNA $\geq 2,000 \mathrm{IU} / \mathrm{ml}$ or liver stiffness $\geq 6.5 \mathrm{kPa}$ or ALT $\geq 40$ IU/L, were invited for liver biopsy. Histopathologists in UK scored liver fibrosis using Metavir system [19]. The study was approved by the Gambia Government/MRC Joint Ethics Committee and conducted according to the guidelines of the Declaration of Helsinki. 


\section{Laboratory assays}

HBsAg was detected by radioimmunoassay (Ausria-I, Abbott, USA) in 1974 [12], reverse passive hemagglutination assay (Wellcotest, Wellcome Diagnostics, UK) in 1980-1998 [15], immunochromatography (Determine, Abbott) in 2003-2008 [20], and chemiluminescent microparticle immunoassay (Architect, Abbott) in 2012-2013 [21]. HBsAg-positive samples were tested for HBeAg by radioimmunoassay in 1980-1998 [15] and later by enzyme immunoassay (EIA) (Diasorin, Biomedica, Italy) [20]. The serological tests were strongly correlated with one another [20,21]. HBV DNA levels were measured at the end of the study in stored samples collected in 1984, 1989, 1993, 2003, 2008, and 2012-2013, using in-house quantitative real-time polymerase chain reaction (detection limit: $50 \mathrm{IU} / \mathrm{ml}$ ), calibrated against an international standard [22]. As previously reported, samples collected in 2003 were examined for $\mathrm{HBV}$ genotype and an $\mathrm{AGG} \rightarrow \mathrm{AGT}$ mutation at codon 249 of p53 tumor suppressor gene (p53R249S) in cell-free DNA, a biomarker of chronic aflatoxin B1 exposure [23]. Samples collected in 2012-2013 were tested for alpha-fetoprotein and antibodies to Hepatitis C virus (HCV) using microparticle EIA (AxSYM, Abbott), antibodies to Hepatitis D virus (HDV) using EIA (ETI-AB-DELTAK-2, Diasorin), and antibodies to HIV-1/2 and p24 antigen using EIA (Genscreen-ULTRA, Bio-Rad, USA). Schistosoma mansoni infection is rare in The Gambia [24] and therefore was not investigated.

\section{Ascertainment of liver disease and death}

Significant liver fibrosis, severe fibrosis and cirrhosis was defined as $\geq F 2, \geq F 3$ and $F 4$ (Metavir) for those who had liver histopathology and liver stiffness $\geq 7.9, \geq 8.2$ and $\geq 9.5 \mathrm{kPa}$ for those without biopsy. These cut-offs were determined by our validation study in The 
Gambia, where the sensitivity of Fibroscan to predict $\geq$ F 2 was $81 \%$ and the specificity was $81 \%$ [25]. The EASL criteria for antiviral therapy are: i) viral load $\geq 2,000 \mathrm{IU} / \mathrm{ml}$ and significant fibrosis, or ii) viral load $\geq 2,000 \mathrm{IU} / \mathrm{ml}$ and moderate/severe active necroinflammation $(\geq \mathrm{A} 2$ by Metavir activity grade), or iii) viral load $\geq 20,000 \mathrm{IU} / \mathrm{ml}$ and $\mathrm{ALT} \geq 80 \mathrm{IU} / \mathrm{L}$, or iv) detectable viral load and cirrhosis [10]. The WHO criteria are: i) clinically diagnosed cirrhosis, or ii) aspartate transaminase (AST)-to-platelet ratio index (APRI) $>2.0$, or iii) $\geq 30$ years old and abnormal ALT and HBV DNA $>20,000 \mathrm{IU} / \mathrm{ml}$ [3]. The phases of the natural history of chronic HBV infection were described [10,26] for the baseline and 2012-2013 survey (supplementary table 2).

HCC cases were identified through a follow-up examination, review of medical records in the MRC Keneba Clinic, or by data linkage with the Gambia National Cancer Registry [27]. The diagnosis was based on the identification of a focal hepatic lesion consistent with HCC on the ultrasound and elevated serum alpha-fetoprotein ( $\geq 200 \mathrm{ng} / \mathrm{ml}$ ). ESLD includes HCC and nonmalignant ESLD. The latter was defined as cirrhosis without HCC and the presence of ascites, hepatic encephalopathy, or hematemesis. The date of death was ascertained through a review of the medical chart in the MRC or data linkage with the West Kiang Demographic Surveillance System [28].

\section{Statistical analyses}

The person-years of follow-up for $\mathrm{HBeAg} / \mathrm{HBsAg}$ clearance, HCC, ESLD, or death were calculated from the date they were identified as HBsAg-positive to the date of endpoint or last follow-up, whichever came first. The date of sero-clearance was defined as the midpoint between the last positive and the first negative result. The cumulative incidence was estimated 
as a function of age using the Kaplan-Meier Method. Age was used rather than time since entry into the study because most infections occur during early childhood [13], and therefore age approximates the duration of $\mathrm{HBV}$ infection. The associations between maternal $\mathrm{HBsAg}$, as recorded at the recruitment of the child, and the $\mathrm{HBeAg} / \mathrm{HBsAg}$ loss were examined using Poisson regression with robust standard error to account for clustering in children that share the same mother. The models included current age, calendar year, sex, and birthplace as covariates. The effect of maternal HBsAg on ALT and HBV DNA ( $\log _{10}$ transformed) was quantified using a linear mixed model with random intercept and random slope to account for the multiple measurements made on the same individuals over time. The detection limit of the assay was assigned to samples with undetectable viral load. The effect of maternal HBsAg on significant fibrosis and meeting antiviral treatment criteria was estimated using logistic regression to control for age, sex, and birthplace (partial model), and additionally for HBV genotype and p53R249S (full model).

Population attributable fractions were calculated [29] for the effects of maternal sero-status on chronic HBV infection and HBV-related liver disease (significant fibrosis and meeting the EASL treatment criteria). This analysis included all the survey participants (1974-2008) with available maternal sero-status who did not receive hepatitis B vaccine. It was not restricted to chronic carriers so that the twofold effect of mother-to-infant transmission could be estimated, i.e., the increased risk of both chronic infection [30], and of liver disease progression in those with established chronic infection [8,9]. All analyses were performed using STATA 11.0 (Stata Corporation, USA). 


\section{RESULTS}

\section{Baseline characteristics}

Between 1974 and 2008, 551 villagers tested positive for HBsAg at least once in the Keneba/Manduar sero-surveys. None had HCC at enrolment. Twenty-nine HBsAg-positive villagers did not participate in any subsequent sero-surveys. These individuals did not differ from the rest of HBsAg-positive individuals in sex, age, HBeAg, HBV DNA and ALT levels at baseline. Finally, there were 405 chronic carriers (figure 1). The median length of followup was 28.4 years (IQR: 17.7-32.7) with the median number of six sero-surveys (IQR: 3-8). The median age at recruitment was 10.8 years (IQR: 4.6-21.8). Half were male, and 65.2\%, $26.1 \%$, and $8.7 \%$ had a mother who was HBsAg-negative, HBsAg-positive/HBeAg-negative, and HBsAg-positive/HBeAg-positive, respectively (table 1). The children of positive mothers had high viral load $(\mathrm{p}=0.04)$ and abnormal ALT levels $(\mathrm{p}=0.05)$ at baseline. Thirty became chronic carriers despite having been fully vaccinated against HBV; median age at the first vaccine was 34 days and none received within three days of birth, and the majority $(60.9 \%$, 14/23) had HBsAg-positive mothers. In the 2003 sero-survey, 95.1\% (97/102) had genotype E and the rest genotype $\mathrm{A} ; 44.2 \%(100 / 226)$ had the p53R249S mutation [23]. 
Table 1. Baseline characteristics of people with chronic HBV infection by maternal HBsAg status $(\mathrm{N}=405)$

\begin{tabular}{|c|c|c|c|c|c|c|}
\hline \multicolumn{2}{|l|}{ Variables } & All $(\mathrm{N}=405)$ & $\begin{array}{l}\text { Unknown } \\
\text { maternal } \\
\text { sero-status } \\
(\mathrm{n}=152)\end{array}$ & $\begin{array}{l}\text { With } \\
\text { HBsAg(+) } \\
\text { mother } \\
(\mathrm{n}=88)\end{array}$ & $\begin{array}{l}\text { With } \\
\text { HBsAg(-) } \\
\text { mother } \\
(\mathrm{n}=165)\end{array}$ & $\begin{array}{l}\text { p- } \\
\text { value }^{1}\end{array}$ \\
\hline \multirow[t]{2}{*}{ Sex } & Male & $204(50 \%)$ & $63(41 \%)$ & $48(55 \%)$ & $93(56 \%)$ & 0.8 \\
\hline & Female & $201(50 \%)$ & $89(59 \%)$ & $40(45 \%)$ & $72(44 \%)$ & \\
\hline \multirow{5}{*}{$\begin{array}{l}\text { Age group } \\
\text { (years) }\end{array}$} & $<5$ & $109(27 \%)$ & $4(3 \%)$ & $42(48 \%)$ & $63(38 \%)$ & $0.9^{2}$ \\
\hline & $5-9$ & $83(20 \%)$ & $9(6 \%)$ & $22(25 \%)$ & $52(32 \%)$ & \\
\hline & $10-14$ & $56(14 \%)$ & $16(10 \%)$ & $8(9 \%)$ & $32(19 \%)$ & \\
\hline & $15-19$ & $39(10 \%)$ & $23(15 \%)$ & $5(6 \%)$ & $11(7 \%)$ & \\
\hline & $\geq 20$ & $118(29 \%)$ & $100(66 \%)$ & $11(12 \%)$ & $7(4 \%)$ & \\
\hline \multirow[t]{2}{*}{ Birth place } & Keneba & $233(58 \%)$ & $106(70 \%)$ & $39(44 \%)$ & $88(53 \%)$ & 0.4 \\
\hline & Manduar & $172(42 \%)$ & $46(30 \%)$ & $49(56 \%)$ & $77(47 \%)$ & \\
\hline \multirow{2}{*}{$\begin{array}{l}\text { Hepatitis } \\
\text { B vaccine }\end{array}$} & Never & $375(93 \%)$ & $145(95 \%)$ & $74(84 \%)$ & $156(95 \%)$ & 0.02 \\
\hline & Ever & $30(7 \%)$ & $7(5 \%)$ & $14(16 \%)$ & $9(5 \%)$ & \\
\hline \multirow[t]{2}{*}{$\mathrm{HBeAg}$} & Negative & $213(55 \%)$ & $118(86 \%)$ & $30(34 \%)$ & $65(40 \%)$ & 0.4 \\
\hline & Positive & $173(45 \%)$ & $19(14 \%)$ & $58(66 \%)$ & $96(60 \%)$ & \\
\hline \multirow{3}{*}{$\begin{array}{l}\text { HBV } \\
\text { DNA } \\
(\mathrm{IU} / \mathrm{ml})\end{array}$} & $<2,000$ & $222(57 \%)$ & $121(83 \%)$ & $30(35 \%)$ & $71(45 \%)$ & $0.04^{2}$ \\
\hline & $2,000-10^{8}$ & $90(23 \%)$ & $20(14 \%)$ & $19(22 \%)$ & $51(32 \%)$ & \\
\hline & $\geq 10^{8}$ & $79(20 \%)$ & $5(3 \%)$ & $37(43 \%)$ & $37(23 \%)$ & \\
\hline \multirow{2}{*}{$\begin{array}{l}\text { ALT } \\
(\mathrm{IU} / \mathrm{L})\end{array}$} & $<40$ & $367(94 \%)$ & $134(92 \%)$ & $77(91 \%)$ & $156(97 \%)$ & 0.05 \\
\hline & $\geq 40$ & $25(6 \%)$ & $12(8 \%)$ & $8(9 \%)$ & $5(3 \%)$ & \\
\hline \multirow{5}{*}{$\begin{array}{l}\text { Phase of } \\
\text { natural } \\
\text { history }\end{array}$} & $\begin{array}{l}\text { Immune } \\
\text { tolerant }\end{array}$ & $116(29 \%)$ & $8(5 \%)$ & $42(48 \%)$ & $66(40 \%)$ & 0.1 \\
\hline & $\begin{array}{l}\mathrm{HBeAg}(+) \\
\text { chronic } \\
\text { hepatitis }\end{array}$ & $14(3 \%)$ & $5(3 \%)$ & $7(8 \%)$ & $2(1 \%)$ & \\
\hline & $\begin{array}{l}\mathrm{HBe} A g(-) \\
\text { chronic } \\
\text { hepatitis }\end{array}$ & $11(3 \%)$ & $7(5 \%)$ & $1(1 \%)$ & $3(2 \%)$ & \\
\hline & Inactive carrier & $190(47 \%)$ & $117(77 \%)$ & $22(25 \%)$ & $51(31 \%)$ & \\
\hline & Unclassified & $74(18 \%)$ & $15(10 \%)$ & $16(18 \%)$ & $43(26 \%)$ & \\
\hline \multirow{2}{*}{$\begin{array}{l}\text { HBV } \\
\text { genotype }^{3}\end{array}$} & Genotype A & $5(5 \%)$ & $1(3 \%)$ & $2(8 \%)$ & $2(5 \%)$ & 0.6 \\
\hline & Genotype E & $97(95 \%)$ & $33(97 \%)$ & $24(92 \%)$ & $40(95 \%)$ & \\
\hline \multirow{2}{*}{$\begin{array}{l}\text { p53R249S } \\
\text { mutation }^{3}\end{array}$} & Negative & $126(56 \%)$ & $50(63 \%)$ & $23(44 \%)$ & $53(56 \%)$ & 0.1 \\
\hline & Positive & $100(44 \%)$ & $30(37 \%)$ & $29(56 \%)$ & $41(44 \%)$ & \\
\hline \multicolumn{2}{|c|}{$\begin{array}{l}\text { Median no. of follow-up } \\
\text { sero-surveys (IQR) }\end{array}$} & $6(3,8)$ & $4(3,6)$ & $6(4,8)$ & $7(5,8)$ & 0.1 \\
\hline \multicolumn{2}{|c|}{$\begin{array}{l}\text { Median years of follow-up } \\
\text { (IQR) }\end{array}$} & $\begin{array}{l}28.4(17.7 \\
32.7)\end{array}$ & $\begin{array}{l}24.4(10.2, \\
37.9)\end{array}$ & $\begin{array}{l}28.6(16.0, \\
32.0)\end{array}$ & $\begin{array}{l}28.7(23.8, \\
32.1)\end{array}$ & 0.2 \\
\hline
\end{tabular}

${ }^{1}$ Comparison was made between participants with HBsAg-positive mothers and HBsAgnegative mothers. P-value and 95\% CI were obtained by Wald test with robust standard error.

${ }^{2}$ Linear test for trend

${ }^{3}$ Determined in a subset of participants in 2003 


\section{HBeAg sero-clearance}

At the enrolment, $213(52.6 \%)$ chronic carriers had already lost HBeAg, The age-specific prevalence of $\mathrm{HBeAg}$ at baseline decreased with increasing age (supplementary figure 1). Of the $173 \mathrm{HBeAg-positive} \mathrm{carriers} \mathrm{at} \mathrm{baseline,} 82.1 \%$ lost $\mathrm{HBeAg}$ and the clearance rate was 7.4\%/year (95\% CI: 6.3-8.8) (table 2, figure 2). Fifteen experienced HBeAg reversion, nine of whom eventually lost $\mathrm{HBeAg}$ whilst six continued to carry $\mathrm{HBeAg}$ until the last follow-up. After adjusting for sex, current age, calendar year and birthplace, the sero-clearance rate was slower in carriers with high HBV DNA levels $\left(\geq 10^{8} \mathrm{IU} / \mathrm{ml}\right)$ at baseline (supplementary table 3). Carriers with HBsAg-positive mothers tend to clear HBeAg slowly, although this did not reach statistical significance (supplementary figure 2-A). 
Table 2. Incidence rates of HBeAg and HBsAg sero-clearance, HCC, ESLD and all-cause mortality in people with chronic HBV infection by gender

\begin{tabular}{|l|c|l|c|l|c|}
\hline Event & $\begin{array}{l}\text { No. of } \\
\text { subjects }\end{array}$ & $\begin{array}{l}\text { Person-years } \\
\text { at risk }\end{array}$ & $\begin{array}{l}\text { No. of } \\
\text { events }\end{array}$ & Rate & $95 \%$ CI \\
\hline HBeAg clearance & 173 & 1912 & 142 & $7.4 / 100$ & $6.3-8.8$ \\
\hline Male & 109 & 1231 & 86 & 7.0 & $5.7-8.6$ \\
\hline Female & 64 & 681 & 56 & 8.2 & $6.3-10.7$ \\
\hline HBsAg clearance & 405 & 8502 & 85 & $1.00 / 100$ & $0.81-1.24$ \\
\hline Male & 204 & 4076 & 32 & 0.79 & $0.56-1.11$ \\
\hline Female & 201 & 4426 & 53 & 1.20 & $0.91-1.57$ \\
\hline HCC & 405 & 10815 & 6 & $55.5 / 100,000$ & $24.9-123.5$ \\
\hline Male & 204 & 5200 & 6 & 115.4 & $51.8-256.8$ \\
\hline Boys (<20 y.o.) & & 1930 & 0 & 0.0 & N/A \\
\hline Adult men ( $\geq 20$ y.o.) & & 3270 & 6 & 183.5 & $82.4-408.5$ \\
\hline Female & 201 & 5615 & 0 & 0.0 & N/A \\
\hline ESLD (including HCC) & 405 & 10815 & 8 & $74.0 / 100,000$ & $37.0-147.9$ \\
\hline Male & 204 & 5200 & 7 & 134.6 & $64.2-282.4$ \\
\hline Female & 201 & 5615 & 1 & 17.8 & $2.5-126.4$ \\
\hline All-cause mortality & 405 & 10815 & 43 & $397.6 / 100,000$ & $294.9-536.1$ \\
\hline Male & 204 & 5200 & 25 & 480.8 & $324.9-711.5$ \\
\hline Female & 201 & 5615 & 18 & 320.6 & $202.0-508.8$ \\
\hline
\end{tabular}




\section{HBsAg sero-clearance}

The rate of HBsAg sero-clearance was 1.0\%/year (95\% CI: 0.8-1.2) (table 2) with half clearing by 57 years old (figure 2). Younger age and high HBV DNA levels at baseline were associated with delayed HBsAg sero-clearance (supplementary table 4). The sero-clearance rate was slower in carriers with HbsAg-positive mothers, but this was not statistically significant (supplementary figure 2-B).

\section{HCC, ESLD, and mortality}

Of the 405 chronic carriers, 43 died; the all-cause mortality rate was $397.6 / 100,000$ personyears (95\% CI: 294.9-536.1). The most common cause of death was HCC (24.0\%) in men and bacterial infection $(22.2 \%)$ in women. All patients with ESLD (including HCC $(n=6)$ and non-malignant $\operatorname{ESLD}(\mathrm{n}=2))$ died within one year of diagnosis. Incidence rates of HCC and ESLD were 55.5 (95\% CI: 24.9-123.5) and 74.0 (95\% CI: 37.0-147.9) per 100,000 personyears, respectively (table 2). All HCC patients were men, all but one was HBeAg-negative at enrolment, and their age at diagnosis ranged between 38 and 67 years (supplementary table 5). The HCC incidence in men $\geq 20$ years was 183.5 (95\% CI: 82.4-408.5) per 100,000 personyears. Maternal sero-status was available in three ESLD patients, and all had HBsAg-positive mothers. Crude incidence rates of HCC in carriers with HBsAg-positive mothers was 89.2/100,000 (95\% CI: 22.3-356.8) while those with negative mothers was $0 / 100,000$ (unadjusted $\mathrm{p}<0.001$ ).

\section{Mean HBV DNA and ALT over time}


The trajectories of HBV DNA and ALT levels by maternal HBsAg are presented in figure 3. Viral load decreased with increasing age at measurement whilst ALT increased. Both viral load and ALT were higher in men than women (supplementary table 6). After adjusting for confounders, the geometric mean viral load was 4.7 times higher $(95 \% \mathrm{CI}: 2.0-11.1, \mathrm{p}<0.001)$ and mean ALT was $4.0 \mathrm{IU} / \mathrm{L}$ higher $(95 \% \mathrm{CI}: 1.2-6.8, \mathrm{p}=0.005)$ in carriers with HBsAgpositive mothers than in those with HBsAg-negative mothers.

\section{Prevalence of chronic liver disease in 2012-2013}

After excluding those who died, 83.1\% (301/362) of chronic HBV carriers participated in the liver assessment in 2012-2013 (figure 1). Participation was lower in men than women, in younger than in older age groups and in carriers with positive $\mathrm{HBeAg}$ at baseline compared with those HBeAg-negative. Table 3 presents the characteristics of the participants. None had ever received antiviral or immunosuppressive therapy. The number co-infected with HIV, $\mathrm{HCV}$, and HDV was three, one, and one, respectively. None had alcohol intake $>20 \mathrm{~g} /$ day based on the standardized questionnaire. Between the baseline and 2012-2013 survey, the proportion of carriers in the immune tolerant phase decreased from $28.6 \%$ to $2.3 \%$ whilst the proportion in the inactive phase increased from $46.9 \%$ to $64.5 \%$ (tables 1 and 3, supplementary figure 3). Only 6.3\% were in HBeAg-negative chronic hepatitis in 2012-2013. Thirty participants had a liver biopsy and 269 had a valid measurement using transient elastography. No liver specimen had steatosis. Fifteen carriers (5.5\%, 95\% CI: 3.4-9.0\%) had significant fibrosis, including nine with severe fibrosis and one with cirrhosis. After controlling for confounders, male gender, genotype A, p53R249S mutation, persistence of HBeAg, high viral load, and ALT were risk factors for significant fibrosis (table 4). After adjusting for sex, age, birthplace, HBV genotype and p53R249S, the odds ratio (OR) for the 
effect of maternal HBsAg on significant fibrosis was 15.8 (95\% CI: 1.4-174.1, p=0.02). Eleven participants $(3.7 \%$, 95\% CI: $2.0-6.5 \%)$ met the EASL treatment criteria. Carriers with an HBsAg-positive mother, HBeAg persistence, frequent high viral load, and abnormal ALT were more likely to require antiviral therapy (table 4$)$. Only five participants $(1.7 \%, 95 \% \mathrm{CI}$ : $0.7-3.9 \%$ ) fulfilled the WHO treatment criteria. 
Table 3. Characteristics of people with chronic HBV infection who participated in the liver assessment 2012-2013 by maternal HBsAg status $(\mathrm{N}=301)$

\begin{tabular}{|c|c|c|c|c|c|}
\hline \multicolumn{2}{|l|}{ Variables } & All $(\mathrm{N}=301)$ & $\begin{array}{l}\text { With HBsAg(+) } \\
\text { mother }(n=66)\end{array}$ & $\begin{array}{l}\text { With HBsAg(-) } \\
\text { mother }(n=123)\end{array}$ & $\begin{array}{l}\mathrm{p}- \\
\text { value }^{1}\end{array}$ \\
\hline \multirow[t]{2}{*}{ Sex } & Male & $130(43 \%)$ & $32(48 \%)$ & $59(48 \%)$ & 0.9 \\
\hline & Female & $171(57 \%)$ & $34(52 \%)$ & $64(52 \%)$ & \\
\hline \multirow{4}{*}{$\begin{array}{l}\text { Current } \\
\text { age group } \\
\text { (years) }\end{array}$} & $<30$ & $46(15 \%)$ & $17(26 \%)$ & $18(14 \%)$ & $0.8^{2}$ \\
\hline & $30-39$ & $117(39 \%)$ & $30(45 \%)$ & $66(54 \%)$ & \\
\hline & $40-49$ & $57(19 \%)$ & $8(12 \%)$ & $28(23 \%)$ & \\
\hline & $\geq 50$ & $81(27 \%)$ & $11(17 \%)$ & $11(9 \%)$ & \\
\hline \multirow{2}{*}{$\begin{array}{l}\text { Birth } \\
\text { place }\end{array}$} & Keneba & $178(59 \%)$ & $27(41 \%)$ & $65(53 \%)$ & 0.3 \\
\hline & Manduar & $123(41 \%)$ & $39(59 \%)$ & $58(47 \%)$ & \\
\hline \multirow{2}{*}{$\begin{array}{l}\text { ALT in } \\
2012 / 2013\end{array}$} & $<40 \mathrm{IU} / \mathrm{L}$ & $268(91 \%)$ & $54(84 \%)$ & $110(93 \%)$ & 0.08 \\
\hline & $\geq 40 \mathrm{IU} / \mathrm{L}$ & $25(9 \%)$ & $10(16 \%)$ & $8(7 \%)$ & \\
\hline \multirow{3}{*}{$\begin{array}{l}\text { HBV } \\
\text { marker in } \\
2012 / 2013\end{array}$} & $\operatorname{HBsAg}(+), \operatorname{HBeAg}(+)$ & $14(5 \%)$ & $6(9 \%)$ & $6(5 \%)$ & $0.3^{2}$ \\
\hline & HBsAg(+), $\operatorname{HBeAg}(-)$ & $227(75 \%)$ & $53(80 \%)$ & $100(81 \%)$ & \\
\hline & HBsAg(-) & $60(20 \%)$ & $7(11 \%)$ & $17(14 \%)$ & \\
\hline \multirow{5}{*}{$\begin{array}{l}\text { HBV } \\
\text { DNA } \\
\text { (IU/ml) in } \\
2012 / 2013\end{array}$} & Undetectable & $135(47 \%)$ & $23(35 \%)$ & $59(50 \%)$ & $0.02^{2}$ \\
\hline & $50-200$ & $65(22 \%)$ & $16(24 \%)$ & $26(22 \%)$ & \\
\hline & $200-2,000$ & $57(20 \%)$ & $13(20 \%)$ & $23(19 \%)$ & \\
\hline & $2,000-20,000$ & $11(4 \%)$ & $4(6 \%)$ & $4(3 \%)$ & \\
\hline & $\geq 20,000$ & $20(7 \%)$ & $10(15 \%)$ & $7(6 \%)$ & \\
\hline \multirow{7}{*}{$\begin{array}{l}\text { Phase of } \\
\text { natural } \\
\text { history in } \\
2012 / 2013\end{array}$} & Immune tolerant & $7(2 \%)$ & $2(3 \%)$ & $4(3 \%)$ & 0.8 \\
\hline & $\begin{array}{l}\mathrm{HBe} \operatorname{Ag}(+) \text { chronic } \\
\text { hepatitis }\end{array}$ & $4(1 \%)$ & $4(6 \%)$ & $0(0 \%)$ & \\
\hline & $\begin{array}{l}\mathrm{HBe} A g(-) \text { chronic } \\
\text { hepatitis }\end{array}$ & $19(6 \%)$ & $6(9 \%)$ & $7(6 \%)$ & \\
\hline & Inactive carrier & $194(65 \%)$ & $41(62 \%)$ & $88(71 \%)$ & \\
\hline & Occult HBV & $12(4 \%)$ & $2(3 \%)$ & $5(4 \%)$ & \\
\hline & Resolved hepatitis B & $48(16 \%)$ & $5(8 \%)$ & $12(10 \%)$ & \\
\hline & Unclassified & $17(6 \%)$ & $6(9 \%)$ & $7(6 \%)$ & \\
\hline
\end{tabular}

${ }^{1}$ p-value from Wald test with robust standard error to take account of clustering among individuals who share the same mother.

${ }^{2}$ Linear test for trend 
Table 4. Factors associated with significant liver fibrosis $(n=271)^{1}$ and condition fulfilling the EASL treatment criteria ( $\left.\mathrm{n}=301\right)$ among people with chronic HBV infection who participated in the liver assessment 2012-13

\begin{tabular}{|c|c|c|c|c|c|c|c|c|c|c|c|}
\hline \multirow{3}{*}{\multicolumn{2}{|c|}{ Variables }} & \multicolumn{5}{|c|}{ Significant liver fibrosis $(n=271)$} & \multicolumn{5}{|c|}{ Meeting the EASL treatment criteria $(n=301)$} \\
\hline & & \multirow{3}{*}{$\begin{array}{l}\text { Proportion } \\
(\%)\end{array}$} & \multicolumn{2}{|l|}{ Crude OR } & \multicolumn{2}{|l|}{ Adjusted $\mathrm{OR}^{3}$} & \multirow{2}{*}{$\begin{array}{l}\text { Proportion } \\
(\%)\end{array}$} & \multicolumn{2}{|c|}{ Crude OR } & \multicolumn{2}{|l|}{ Adjusted $\mathrm{OR}^{3}$} \\
\hline & & & OR $(95 \% \mathrm{CI})^{2}$ & $\mathrm{P}$ & OR $(95 \% \mathrm{CI})^{2}$ & $\mathrm{P}$ & & OR $(95 \% \mathrm{CI})^{2}$ & $\mathrm{P}$ & OR $(95 \% \mathrm{CI})^{2}$ & $\mathrm{P}$ \\
\hline \multirow[t]{2}{*}{ Sex } & Male & & 1.0 (ref) & \multirow[t]{2}{*}{0.01} & 1.0 (ref) & \multirow[t]{2}{*}{$<0.01$} & $5 / 130(4)$ & 1.0 (ref) & \multirow[t]{2}{*}{0.9} & 1.0 (ref) & \multirow[t]{2}{*}{0.9} \\
\hline & Female & $3 / 151(2)$ & $0.2(0.1-0.7)$ & & $0.2(0.1-0.6)$ & & $6 / 171(4)$ & $0.9(0.3-3.0)$ & & $1.0(0.3-3.3)$ & \\
\hline \multirow{4}{*}{$\begin{array}{l}\text { Current age } \\
\text { group } \\
(\text { years) }\end{array}$} & $<30$ & $3 / 43(7)$ & 1.0 (ref) & \multirow[t]{4}{*}{0.6} & 1.0 (ref) & \multirow[t]{4}{*}{0.9} & $3 / 46(7)$ & 1.0 (ref) & \multirow[t]{4}{*}{0.2} & 1.0 (ref) & \multirow[t]{4}{*}{0.2} \\
\hline & $30-39$ & $6 / 107(6)$ & $0.8(0.2-2.9)$ & & $1.1(0.3-4.8)$ & & $5 / 117(4)$ & $0.6(0.1-2.8)$ & & $0.7(0.1-3.0)$ & \\
\hline & $40-49$ & $3 / 50(6)$ & $0.9(0.2-4.5)$ & & $1.1(0.2-6.4)$ & & $1 / 57(2)$ & $0.3(0.1-2.6)$ & & $0.3(0.1-2.8)$ & \\
\hline & $\geq 50$ & $3 / 71(4)$ & $0.6(0.1-2.9)$ & & $1.1(0.2-6.2)$ & & $2 / 81(2)$ & $0.4(0.1-2.3)$ & & $0.4(0.1-2.2)$ & \\
\hline \multirow{2}{*}{\begin{tabular}{|l|} 
Maternal \\
HBsAg \\
\end{tabular}} & Negative & 4/112 (4) & 1.0 (ref) & \multirow[t]{2}{*}{0.01} & 1.0 (ref) & \multirow[t]{2}{*}{$<0.01$} & $2 / 123(2)$ & 1.0 (ref) & \multirow[t]{2}{*}{0.03} & 1.0 (ref) & \multirow[t]{2}{*}{0.03} \\
\hline & Positive & $9 / 61(15)$ & $4.7(1.4-15.9)$ & & $5.0(1.6-15.4)$ & & $6 / 66(9)$ & $6.1(1.2-30.1)$ & & $5.5(1.2-24.4)$ & \\
\hline \multirow{2}{*}{$\begin{array}{l}\text { HBV } \\
\text { genotype }\end{array}$} & Genotype E & $8 / 92(9)$ & 1.0 (ref) & \multirow[t]{2}{*}{0.02} & 1.0 (ref) & \multirow[t]{2}{*}{0.04} & $8 / 101(8)$ & 1.0 (ref) & \multirow[t]{2}{*}{$\mathrm{N} / \mathrm{A}$} & 1.0 (ref) & \multirow[t]{2}{*}{ N/A } \\
\hline & Genotype A & $2 / 3(67)$ & $21.0(1.7-266.1)$ & & $20.7(1.2-368.1)$ & & $0 / 5(0)$ & $\mathrm{N} / \mathrm{A}$ & & $\mathrm{N} / \mathrm{A}$ & \\
\hline \multirow{2}{*}{$\begin{array}{l}\text { R249S } \\
\text { mutation }\end{array}$} & Negative & $3 / 96(3)$ & 1.0 (ref) & \multirow[t]{2}{*}{0.06} & $1.0(\mathrm{ref})$ & \multirow[t]{2}{*}{0.03} & $0 / 111(0)$ & 1.0 (ref) & \multirow[t]{2}{*}{$\mathrm{N} / \mathrm{A}$} & 1.0 (ref) & N/A \\
\hline & Positive & 9/79 (11) & $4.0(1.0-16.4)$ & & $5.1(1.1-23.3)$ & & $8 / 86(9)$ & N/A & & N/A & \\
\hline $\begin{array}{l}\text { Persistence } \\
\text { of } \mathrm{HBeAg}^{4}\end{array}$ & $\begin{array}{l}\text { Negative at } \\
\text { baseline }\end{array}$ & $3 / 158(2)$ & 1.0 (ref) & $<0.01$ & 1.0 (ref) & $<0.01$ & $2 / 178(1)$ & 1.0 (ref) & $<0.01$ & 1.0 (ref) & $<0.01$ \\
\hline & $\begin{array}{l}\text { Cleared } \\
\text { during F/U }\end{array}$ & $8 / 101(8)$ & $4.4(1.2-16.7)$ & & $12.0(1.1-134.1)$ & & $5 / 109(5)$ & $4.2(0.8-22.0)$ & & $9.4(0.5-165.9)$ & \\
\hline & $\begin{array}{l}\text { Still } \\
\text { positive }\end{array}$ & $4 / 12(33)$ & $25.8(5.4-123.8)$ & & $\begin{array}{l}125.5(9.5- \\
1650.9) \\
\end{array}$ & & $4 / 14(29)$ & $35.2(6.0-205.1)$ & & $\begin{array}{l}111.9(5.9- \\
2138.1)\end{array}$ & \\
\hline \% samples & Never & $2 / 109(2)$ & 1.0 (ref) & $<0.01$ & 1.0 (ref) & 0.02 & $1 / 129(1)$ & 1.0 (ref) & $<0.01$ & 1.0 (ref) & $<0.01$ \\
\hline with HBV & $<50 \%$ & $5 / 83(6)$ & $3.4(0.7-17.9)$ & & $4.9(0.7-36.2)$ & & $1 / 88(1)$ & $1.4(0.1-24.1)$ & & $3.2(0.3-37.3)$ & \\
\hline $\begin{array}{l}\text { DNA } \\
\geq 2,000\end{array}$ & $\geq 50 \%$ & $8 / 48(17)$ & $10.7(2.2-52.0)$ & & $15.5(1.5-164.1)$ & & $9 / 53(17)$ & $26.2(3.3-209.9)$ & & $\begin{array}{l}123.9(10.5- \\
1461.4)\end{array}$ & \\
\hline
\end{tabular}




\begin{tabular}{|c|c|c|c|c|c|c|c|c|c|c|c|}
\hline $\mathrm{IU} / \mathrm{ml}^{4,5}$ & & & & & & & & & & & \\
\hline \multirow{3}{*}{$\begin{array}{l}\% \text { samples } \\
\text { with ALT } \\
\geq 40 \mathrm{IU} / \mathrm{L}^{4,5}\end{array}$} & Never & $5 / 208(2)$ & 1.0 (ref) & \multirow[t]{3}{*}{$<0.01$} & 1.0 (ref) & \multirow[t]{3}{*}{$<0.01$} & $3 / 233(1)$ & 1.0 (ref) & \multirow[t]{3}{*}{$<0.01$} & 1.0 (ref) & \multirow[t]{3}{*}{$<0.01$} \\
\hline & $<50 \%$ & $3 / 14(21)$ & $11.1(2.3-52.5)$ & & $7.7(1.6-36.8)$ & & $2 / 14(14)$ & $12.8(1.9-84.9)$ & & $13.6(1.7-106.5)$ & \\
\hline & $\geq 50 \%$ & $5 / 20(25)$ & $13.5(3.6-50.7)$ & & $17.2(2.5-118.6)$ & & $5 / 23(22)$ & $21.3(4.6-99.3)$ & & $27.6(3.8-200.1)$ & \\
\hline
\end{tabular}

10 Excluding participants who did not have a liver biopsy and who had invalid measurements with transient elastography.

${ }^{2}$ p-value and $95 \%$ CI were obtained by Wald test with robust standard error to take account of clustering among individuals who share the same mother.

${ }^{3}$ OR adjusted for sex, current age and birthplace.

${ }^{4}$ Test for linear trend.

${ }^{5}$ This only includes subjects who had at least two measurements during the follow-up. 


\section{Population attributable fractions}

Maternal sero-status was recorded in 977 unvaccinated participants in Keneba/Manduar between 1974 and 2008, among whom 230 became chronic HBV carriers. The mother was HBsAg-positive in $32.2 \%$ of all the chronic carriers, $64.3 \%$ of carriers with significant fibrosis, and $71.4 \%$ of carriers requiring antiviral treatment according to the EASL guidelines. After controlling for age and sex, having an HBsAg-positive mother was associated with chronic carriage (OR: 2.0, 95\% CI: 1.3-3.1), significant fibrosis (OR: 6.4, 2.1-19.8), and requiring antiviral treatment (OR: 8.5, 1.8-40.9). Consequently, the population attributable fraction, that is the proportion of chronic carriers attributable to having an HBsAg-positive mother was $16.0 \%$ (95\% CI: 8.6-22.9\%), and the population attributable fractions for HBVrelated significant fibrosis and cases requiring antiviral treatment were 54.3\% (41.5-64.3\%) and $63.0 \%(47.0-74.1 \%)$, respectively.

\section{DISCUSSION}

This is the first long-term follow-up of a population-based cohort of chronic HBV carriers in SSA $[3,31,32]$. We confirmed that the age-standardized rate of HCC in the chronic carriers in this study $(67.3 / 100,000)$ was much higher than in the general population in The Gambia $(22.1 / 100,000)$ [27], which highlights the importance of controlling chronic HBV infection to prevent HCC. Of note, only $3.7 \%$ and $1.7 \%$ of chronic carriers assessed in $2012-2013$ met the EASL and WHO criteria for antiviral treatment, respectively, making HBV a tractable health problem. The PROLIFICA project, the first treatment program for HBV mono-infected 
individuals in SSA, will assess the effectiveness of HBV screening and antiviral therapy in reducing HCC in The Gambia and Senegal.

The incidence rate of HCC in adult men with chronic HBV infection differs considerably by geographical location: 34/100,000 carrier-years in Europe [33], 230/100,000 in Alaska [34], 327/100,000 in New Zealand Maori [35] and 530-880/100,000 in East Asia [36,37]. In SSA, the recorded rates in adult male lie between Europe and Asia $(68.3 / 100,000$ in Senegalese army [36] and 183.5/100,000 in our population-based cohort). These variations in HCC incidence might be partly explained by a difference in the natural history of chronic HBV infection as is discussed below.

It is well established that persistence of high $\mathrm{HBV}$ viral load [37,38] or $\mathrm{HBeAg}$ [39] increases the risk of HCC, and the current study also confirmed an elevated risk of significant fibrosis in carriers with these conditions. In contrast to East Asia where about half of carrier children remain HBeAg-positive into their twenties [40], in SSA, decay of viral replication occurs much faster. We found that half of chronic carriers lost HBeAg by the age of puberty, and amongst those who cleared, the majority became inactive carriers with low or undetectable HBV DNA, and few developed HCC or HBeAg-negative chronic hepatitis.

Another question is what determines the difference in trajectory of viral replication between Asia and SSA. Evans et al. argued that the difference can be explained by the major mode of HBV transmission [36]: in East Asia 40\% of chronic carriers were infected vertically compared with only $10 \%$ in SSA before the introduction of hepatitis B vaccine [6]. In our study we estimated that $16 \%$ of chronic infection attributable to mother-to-infant transmission. 
We found that having an HBsAg-positive mother, which is a proxy for mother-to-infant transmission that occurs perinatally or during early childhood, was a risk factor for maintenance of viremia in The Gambia. Moreover, maternal HBsAg was also associated with high ALT, higher prevalence of significant fibrosis and treatment eligibility, and higher HCC incidence among chronic carriers. By restricting to chronic carriers, our analysis suggests that maternal transmission not only increases the risk of chronic infection [30] but may also further increase the risk of persistent viral replication and severe liver disease [8]. These findings are consistent with previous Asian studies that assessed the effect of maternal HBV status [7,8]. Persistent HBV replication may be facilitated in infants because they have an immature immune system [32].

In the pre-vaccine era, horizontal transmission during childhood was more common than perinatal maternal transmission in SSA, and our data support this $(16.0 \%$ of chronic infection attributable to mother-to-infant transmission). However, we also found that only $3.7 \%$ of chronic carriers required antiviral therapy, and most of these cases $(63.0 \%)$ were attributable to mother-to-infant transmission. This population attributable fraction may even be higher in the post-vaccine era, because the first dose of hepatitis B vaccine is usually delayed for more than one week and therefore perinatal maternal transmission is not well prevented in The Gambia $[4,41,42]$. Indeed, in our cohort, $60.9 \%$ of children who became chronic carriers despite having been fully vaccinated had HBsAg-positive mothers and none received the first vaccine at birth, implying that they were already infected from their mothers before the vaccination.

These findings suggest the importance of interrupting mother-to-infant transmission to reduce the HBV-related disease burden in SSA. Although the WHO recommends a timely 
administration of hepatitis B vaccine within 24 hours of birth to prevent perinatal and early horizontal transmission [3,5], only $11 \%$ of newborns currently receive a birth dose in SSA [43]. This is partly because birth dose is difficult to implement in population where many births take place at home, but also because the Global Alliance for Vaccines and Immunization (GAVI) only provides the pentavalent vaccine (DTP-HepB-Hib), which cannot be used at birth. The feasibility and cost-effectiveness of a timely birth dose vaccine or other strategy (e.g., antiviral therapy for infectious pregnant women) needs to be investigated in SSA [44].

The study is also the first longitudinal cohort to show the association between p53R249S, a marker of chronic aflatoxin exposure, and liver fibrosis. Moreover, we also found a differential risk in liver disease between genotypes $\mathrm{A}$ and $\mathrm{E}$, although the number infected with genotype A was small. In West and Central Africa, genotype E is predominant followed by $\mathrm{A}$, whereas in Asia genotype $\mathrm{C}$ is common [45]. The latter is associated with delayed HBeAg loss compared with genotypes A, B, D, and F [46], and this may explain why persistent viral replication is more common in East Asia than SSA. Unfortunately, a direct comparison of clinical outcomes between genotype $\mathrm{C}$ and $\mathrm{E}$ is difficult because their geographical distributions do not overlap.

The American Guidelines for chronic HBV infection recommend starting the screening for HCC in African HBV carriers at an early age ( $\geq 20$ years old) [26]. This is based on several African case-series where a young median age at HCC diagnosis was reported $[9,47]$. However, of six HCC cases in this study only one (17\%) was $<40$ years old. This needs to be further studied as this recommendation is costly. 
Our study has several limitations. First, the interval between follow-up sero-surveys (4-5 years) was longer than other longitudinal studies $[34,35,48]$ which might have affected the estimates of $\mathrm{HBeAg} / \mathrm{HBsAg}$ sero-clearance. Nonetheless, the rates are within a range that has been previously reported (HBeAg clearance: 6-9\%/year, HBsAg clearance: $0.5-1.6 \% /$ year) $[34,35,48]$. Second, ideally, we would have used maternal HBeAg status at the birth of the child as a proxy for mother-to-infant transmission, since maternal $\mathrm{HBeAg}$ positivity is a stronger predictor of maternal transmission than HBsAg. However, maternal sero-status was determined when the child entered the cohort, and by this time maternal $\mathrm{HBeAg}$ is likely to have been lost [8]. Third, the phases of the natural history of chronic HBV infection might have been incorrectly classified as they were determined on a single assessment rather than longitudinal monitoring. Fourth, HBV DNA was measured in historical samples, and its levels might have been affected by a prolonged storage and multiple freeze-thaw cycles. Nevertheless, the effect of freeze-thaw cycles is reported to be minimal for HBV DNA assays [49]. Finally, the HCC cases were ascertained through linkage with the cancer registry database, which is estimated to record only $50 \%$ of cases [50]. We attempted to mitigate this bias by also reviewing medical records at the local clinic.

In conclusion, compared to East Asia, the natural history of chronic HBV infection in West Africa is characterized by a shorter duration of viremia and lower incidence of $\mathrm{HCC}$, which is probably due to the lower frequency of mother-to-infant transmission in SSA. Among those who develop severe liver disease in The Gambia the majority are infected by their mothers, emphasizing the importance of interrupting perinatal transmission in SSA. 


\section{ACKNOWLEDGEMENT}

The Gambia Government, MRC and European Commission's Seventh Framework Program (grant 265994) supported the study. We thank Saydiba Tamba, Yaya Minteh and MomodouLamin Jobarteh for fieldwork, Bai-Lamin Dondeh, Safayet Hossin and Tony Fulford for data management, Debbie Garside for study coordination and Pierre Hainaut and Stephanie Villar for the p53R249S mutation study.

\section{COMPETING INTERESTS}

We declare that we have no conflict of interest.

\section{FUNDING}

European Commission’s Seventh Framework Program (grant 265994)

\section{AUTHOR CONTRIBUTIONS}

YS drafted the manuscript, and all the authors reviewed and approved it. HW initiated and MM maintained the cohort. YS, ML, RN, and MTh were responsible for the design of the liver assessment 2012-2013; YS and AJ for fieldwork; ML, GN, and RN for clinical work; HFN and AJB for laboratory assays; RDG for histopathological analysis; YS and CB for statistical analysis. RW, SM, IB, MTa, and UDA supported the conduct of the study. 


\section{REFERENCES}

1 Cowie BC, MacLachlan JH. The global burden of liver disease attributable to hepatitis $\mathrm{B}$, hepatitis $\mathrm{C}$, and alcohol: increasing mortality, differing causes. Hepatology 2013;58:218A - 219A.

2 Kiire CF. The epidemiology and prophylaxis of hepatitis B in sub-Saharan Africa: a view from tropical and subtropical Africa. Gut 1996;38:S5-12.

3 WHO. Guidelines for the prevention, care and treatment of persons with chronic hepatitis B infection. Geneva, Switzerland: 2015.

4 Mendy M, Peterson I, Hossin S, et al. Observational study of vaccine efficacy 24 years after the start of hepatitis B vaccination in two Gambian villages: no need for a booster dose. PLoS One 2013;8:e58029. doi:10.1371/journal.pone.0058029

5 WHO. Hepatitis B vaccines. WHO position paper. Wkly Epidemiol Rec 2009;84:40520.

6 Edmunds WJ, Medley GF, Nokes DJ, et al. Epidemiological patterns of hepatitis B virus (HBV) in highly endemic areas. Epidemiol Infect 1996;117:313-25.

7 Chang M-H. Natural history and clinical management of chronic hepatitis B virus infection in children. Hepatol Int 2008;2:S28-36.

8 Shimakawa Y, Yan H-J, Tsuchiya N, et al. Association of early age at establishment of chronic hepatitis B infection with persistent viral replication, liver cirrhosis and hepatocellular carcinoma: a systematic review. PLoS One 2013;8:e69430. doi:10.1371/journal.pone.0069430

9 Shimakawa Y, Lemoine M, Bottomley C, et al. Birth order and risk of hepatocellular carcinoma in chronic carriers of hepatitis B virus: a case-control study in The Gambia. Liver Int Published Online First: 26 February 2015. doi:10.1111/liv.12814

10 European Association for the Study of the Liver. EASL clinical practice guidelines: Management of chronic hepatitis B virus infection. J Hepatol 2012;57:167-85. doi:10.1016/j.jhep.2012.02.010

11 McGregor IA. Health and Communicable Disease in a Rural African Environment. Oikos 1976;27:180-92.

12 Whittle HC, Bradley AK, McLauchlan K. Hepatitis B virus infection in two Gambian villages. Lancet 1983;1:1203-6. 
13 Whittle HC, Inskip H, Bradley AK, et al. The Pattern of Childhood Hepatitis B Infection in Two Gambian Villages. J Infect Dis 1990;161:1112-5. doi:10.1093/infdis/161.6.1112

14 Whittle HC, Inskip H, Hall AJ, et al. Vaccination against hepatitis B and protection against chronic viral carriage in The Gambia. Lancet 1991;337:747-50.

15 Whittle HC, Pilkington J, Maine N, et al. Long-term efficacy of continuing hepatitis B vaccination in infancy in two Gambian villages. Lancet 1995;345:1089-92. doi:10.1016/S0140-6736(95)90822-6

16 Whittle HC, Jaffar S, Wansbrough M, et al. Observational study of vaccine efficacy 14 years after trial of hepatitis B vaccination in Gambian children. BMJ 2002;325:569.

17 Van der Sande MAB, Waight P, Mendy M, et al. Long-term protection against carriage of hepatitis B virus after infant vaccination. J Infect Dis 2006;193:1528-35. doi: $10.1086 / 503433$

18 Shimakawa Y, Lemoine M, Mendy M, et al. Population-based interventions to reduce the public health burden related with hepatitis B virus infection in The Gambia, West Africa. Trop Med Heal 2014;42:59-64. doi:10.2149/tmh.2014-S08

19 Bedossa P, Poynard T. An algorithm for the grading of activity in chronic hepatitis C. Hepatology 1996;24:289-93. doi:10.1053/jhep.1996.v24.pm0008690394

20 Mendy ME, McConkey SJ, van der Sande MAB, et al. Changes in viral load and HBsAg and HBeAg status with age in HBV chronic carriers in The Gambia. Virol J 2008;5:49. doi:10.1186/1743-422X-5-49

21 Njai HF, Shimakawa Y, Sanneh B, et al. Validation of rapid point-of-care (POC) tests for the detection of hepatitis B surface antigen (HBsAg) in field and laboratory settings in The Gambia, West Africa. J Clin Microbiol 2015;53:1156-63. doi:10.1128/JCM.02980-14

22 Mendy ME, Kaye S, van der Sande M, et al. Application of real-time PCR to quantify hepatitis B virus DNA in chronic carriers in The Gambia. Virol J 2006;3:23. doi:10.1186/1743-422X-3-23

23 Villar S, Le Roux-Goglin E, Gouas DA, et al. Seasonal variation in TP53 R249Smutated serum DNA with aflatoxin exposure and hepatitis B virus infection. Environ Health Perspect 2011;119:1635-40.

24 Schur N, Hürlimann E, Garba A, et al. Geostatistical Model-Based Estimates of Schistosomiasis Prevalence among Individuals Aged 20 Years in West Africa. PLoS Negl Trop Dis 2011;5:e1194. doi:10.1371/journal.pntd.0001194 
25 Lemoine M, Shimakawa Y, Nayagam S, et al. The Gamma-glutamyl transpeptidase to Platelet Ratio (GPR) predicts significant liver fibrosis and cirrhosis in patients with chronic hepatitis B virus infection in West Africa. Gut 2015; in press.

doi:10.1136/gutjnl-2015-309260

Lok ASF, McMahon BJ. Chronic hepatitis B: update 2009. Hepatology 2009;50:661-2. doi:10.1002/hep. 23190

27 Bah E, Carrieri MP, Hainaut P, et al. 20-years of population-based cancer registration in hepatitis B and liver cancer prevention in the Gambia, West Africa. PLoS One 2013;8:e75775. doi:10.1371/journal.pone.0075775

28 MRC Unit The Gambia. The West Kiang Demographic Surveillance System (DSS). http://www.mrc.gm/our-research/themes/nutrition/ing-research-areas/west-kiangdemographic-surveillance-system-dss/ (accessed 20 Mar2015).

29 Rothman KJ, Greenland S, Lash TL. Modern Epidemiology. Lippincott Williams \& Wilkins,US 2008.

30 Hyams KC. Risks of Chronicity Following Acute Hepatitis B Virus Infection: A Review. Clin Infect Dis 1995;20:992-1000. doi:10.1093/clinids/20.4.992

31 Lin X, Robinson NJ, Thursz M, et al. Chronic hepatitis B virus infection in the AsiaPacific region and Africa: review of disease progression. $J$ Gastroenterol Hepatol 2005;20:833-43. doi:10.1111/j.1440-1746.2005.03813.x

32 Hadziyannis SJ. Natural history of chronic hepatitis B in Euro-Mediterranean and African countries. J Hepatol 2011;55:183-91. doi:10.1016/j.jhep.2010.12.030

33 Crook PD, Jones ME, Hall AJ. Mortality of hepatitis B surface antigen-positive blood donors in England and Wales. Int J Epidemiol 2003;32:118-24. doi:10.1093/ije/dyg039

34 McMahon BJ, Holck P, Bulkow L, et al. Serologic and clinical outcomes of 1536 Alaska Natives chronically infected with hepatitis B virus. Ann Intern Med 2001;135:759-68.

35 Lim TH, Gane E, Moyes C, et al. Serological and clinical outcomes of horizontally transmitted chronic hepatitis B infection in New Zealand Māori: results from a 28-year follow-up study. Gut 2015;64:966-72. doi:10.1136/gutjnl-2013-306247

36 Evans A, Connell APO, Pugh JC, et al. Geographic variation in viral load among hepatitis B carriers with differing risks of hepatocellular carcinoma. Cancer Epidemiol Biomarkers Prev 1998;7:559-65.

37 Chen CJ, Yang HI, Su J, et al. Risk of hepatocellular carcinoma across a biological gradient of serum hepatitis B virus DNA level. JAMA 2006;295:65-73. doi:10.1001/jama.295.1.65 
38 Chen C, Lee W, Yang H, et al. Changes in serum levels of HBV DNA and alanine aminotransferase determine risk for hepatocellular carcinoma. Gastroenterology 2011;141:1240-8. doi:10.1053/j.gastro.2011.06.036

39 Chen YC, Chu CM, Liaw YF. Age-specific prognosis following spontaneous hepatitis B e antigen seroconversion in chronic hepatitis B. Hepatology 2010;51:435-44.

40 Chu CM, Liaw YF. Chronic hepatitis B virus infection acquired in childhood: special emphasis on prognostic and therapeutic implication of delayed $\mathrm{HBe} A g$ seroconversion. $J$ Viral Hepat 2007;14:147-52. doi:10.1111/j.1365-2893.2006.00810.x

41 Shimakawa Y, Bottomley C, Njie R, et al. The association between maternal hepatitis $\mathrm{B}$ e antigen status, as a proxy for perinatal transmission, and the risk of hepatitis B e antigenaemia in Gambian children. BMC Public Health 2014;14:532. doi:10.1186/1471-2458-14-532

42 Peto TJ, Mendy ME, Lowe Y, et al. Efficacy and effectiveness of infant vaccination against chronic hepatitis B in the Gambia Hepatitis Intervention Study (1986-90) and in the nationwide immunisation program. BMC Infect Dis 2014;14:7. doi:10.1186/14712334-14-7

43 WHO. Global routine vaccination coverage, 2013. Wkly Epidemiol Rec 2014;89:51722.

44 Howell J, Lemoine M, Thursz M. Prevention of materno-foetal transmission of hepatitis B in sub-Saharan Africa: the evidence, current practice and future challenges. $J$ Viral Hepat 2014;21:381-96. doi:10.1111/jvh.12263

45 Kramvis A, Kew MC. Epidemiology of hepatitis B virus in Africa, its genotypes and clinical associations of genotypes. Hepatol Res 2007;37:S9-19. doi:10.1111/j.1872034X.2007.00098.x

46 Livingston SE, Simonetti JP, Bulkow LR, et al. Clearance of Hepatitis B e Antigen in Patients With Chronic Hepatitis B and Genotypes A, B, C, D, and F. Gastroenterology 2007;133:1452-7.

47 Kew MC, Geddes EW. Hepatocellular carcinoma in rural southern African blacks. Medicine (Baltimore) 1982;61:98-108. doi:10.1097/00005792-198203000-00004

48 Bortolotti F, Guido M, Bartolacci S, et al. Chronic hepatitis B in children after e antigen seroclearance: final report of a 29-year longitudinal study. Hepatology 2006;43:556-62. doi:10.1002/hep.21077

49 Sanlidag T, Akcali S, Ozbakkaloglu B. Serum hepatitis B DNA: Stability in relation to multiple freeze-thaw procedures. $J$ Virol Methods 2005;123:49-52. doi:10.1016/j.jviromet.2004.09.006 
50 Shimakawa Y, Bah E, Wild CP, et al. Evaluation of data quality at the Gambia National Cancer Registry. Int J Cancer 2013;132:658-65. doi:10.1002/ijc. 27646

\section{FIGURE LEGENDS}

Figure 1. Flow diagram of study participants

Figure 2. Proportion of chronic HBV carriers who cleared HBeAg and HBsAg as a function of age*

${ }^{*}$ The number at risk is smaller at 5 and 15 years than at 25 years in the figure for HBsAg because the median age of recruitment was 10.8 years.

Figure 3. Changes with age in serum HBV DNA (A) and ALT levels (B) by maternal HBsAg status (- and + denote negative and positive maternal HBsAg, respectively) amongst chronic HBV carriers*

\footnotetext{
${ }^{*}$ Two outliers (ALT: 166 and $351 \mathrm{IU} / \mathrm{L}$ ) in positive maternal HBsAg group are not presented in the figure $3-\mathrm{B}$.
} 


\title{
Title
}

\author{
Natural history of chronic hepatitis B virus infection in West Africa: a longitudinal \\ population-based study from The Gambia
}

\section{Short Title}

Natural history of chronic hepatitis B in West Africa

\author{
Authors \\ Yusuke Shimakawa, PhD,,${ }^{1,2,3,{ }^{*}}$ Maud Lemoine, PhD,,${ }^{1,4}{ }^{*}$ Harr Freeya Njai, PhD, ${ }^{1}$ Christian \\ Bottomley, PhD,${ }^{2}$ Gibril Ndow, MD,${ }^{1,5}$ Robert D Goldin, MD,${ }^{4}$ Abdoulie Jatta, ${ }^{1}$ Adam Jeng- \\ Barry, ${ }^{1}$ Rita Wegmuller, PhD, ${ }^{6}$ Sophie Moore, PhD, ${ }^{2,6}$ Ignatius Baldeh, MSc, ${ }^{7}$ Makie Taal, \\ PhD,${ }^{7}$ Umberto D'Alessandro, PhD,${ }^{1,2}$ Hilton Whittle, FMedSci, ${ }^{8}$ Ramou Njie, PhD, ${ }^{1,5}$ Mark \\ Thursz, MD, ${ }^{4}$ Maimuna Mendy, $\mathrm{PhD}^{9}$ \\ * Equally contributed
}


${ }^{1}$ Medical Research Council (MRC) Unit, The Gambia. Banjul, The Gambia.

${ }^{2}$ Faculty of Epidemiology and Population Health, London School of Hygiene and Tropical Medicine. London, UK.

${ }^{3}$ Unité d'Épidémiologie des Maladies Émergentes, Institut Pasteur. Paris, France

${ }^{4}$ Department of Hepatology, Imperial College London. London, UK.

${ }^{5}$ The Gambia Hepatitis Intervention Study, IARC, c/o MRC Unit, The Gambia. Banjul, The Gambia.

${ }^{6}$ MRC International Nutrition Group, MRC Keneba. West Kiang, The Gambia.

${ }^{7}$ Ministry of Health and Social Welfare. Banjul, The Gambia.

${ }^{8}$ Faculty of Infectious and Tropical Diseases, London School of Hygiene and Tropical Medicine. London, UK.

${ }^{9}$ International Agency for Research on Cancer (IARC). Lyon, France. 


\section{Correspondence}

Prof Mark Thursz

Department of Hepatology, Imperial College London, Norfolk Place, London, W2 1NY, UK

Email: m.thursz@imperial.ac.uk

Phone +44-(0)2033121903. Fax +44-(0)2077069161.

\section{Keywords}

Hepatitis B; natural history; infectious disease transmission, vertical; Africa

Word Count (excluding title page, abstract, references, figures and tables)

4,000 words 
Abbreviations

ALT

APRI

AST

EASL

EIA

EPI

ESLD

GAVI

$\mathrm{HBeAg}$

HBsAg

HBV

HCC
Alanine transaminase

Aspartate transaminase (AST)-to-Platelet Ratio Index

Aspartate transaminase

European Association for the Study of the Liver

Enzyme immunoassay

Expanded Program on Immunization

End-stage liver disease

Global Alliance for Vaccines and Immunization

Hepatitis B e antigen

Hepatitis B surface antigen

Hepatitis B virus

Hepatocellular carcinoma 


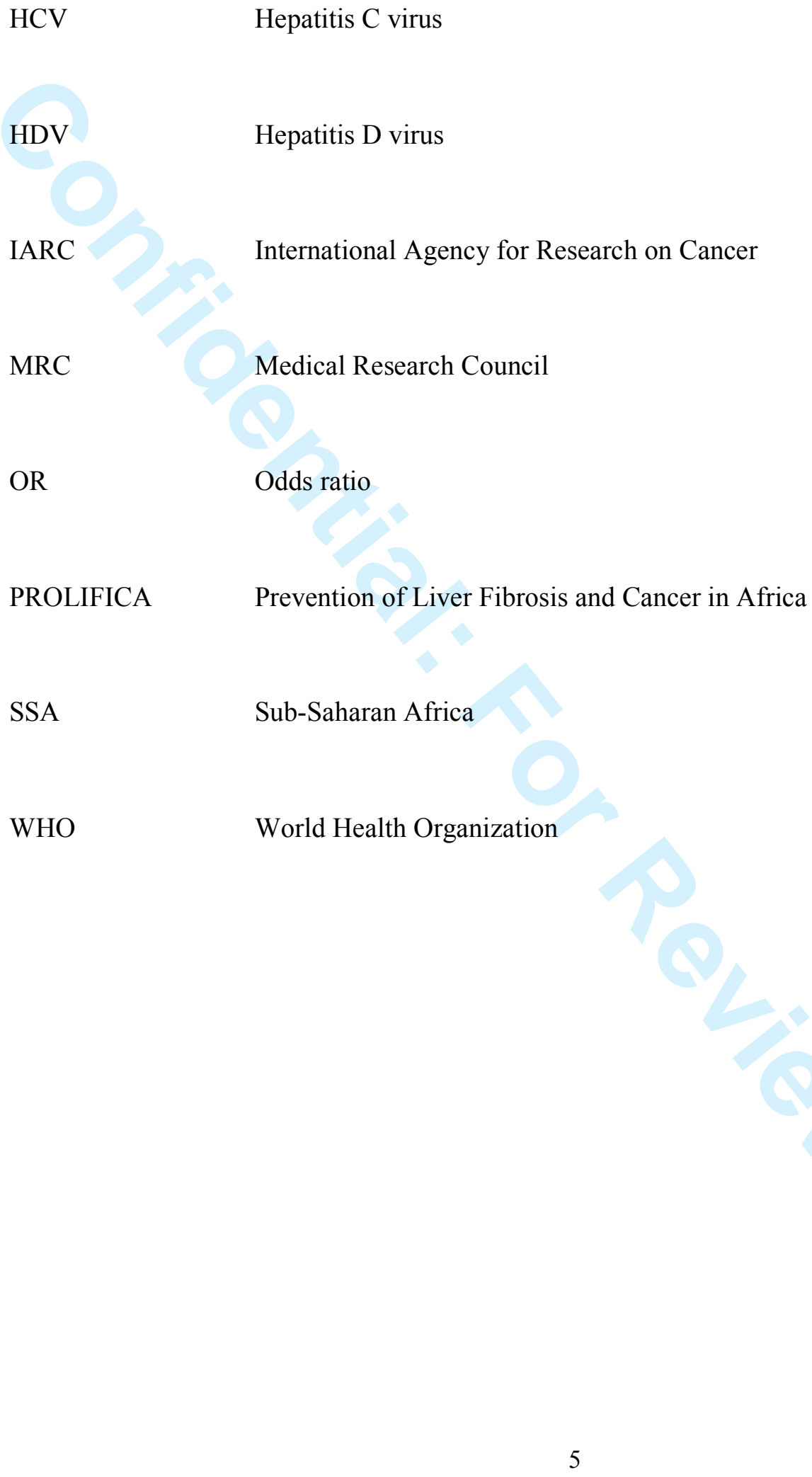




\begin{abstract}
Background

The natural history of chronic hepatitis B virus (HBV) infection in sub-Saharan Africa is unknown. Data is required to inform WHO guidelines which are currently based on studies in Europe and Asia.
\end{abstract}

Methods

Between 1974 and 2008, sero-surveys were repeated in two Gambian villages, and an open cohort of treatment-naïve chronic HBV carriers was recruited. Participants were followed to estimate the rates of hepatitis $\mathrm{B}$ e $(\mathrm{HBeAg})$ and surface antigen ( $\mathrm{HBsAg}$ ) clearance and incidence of hepatocellular carcinoma (HCC). In 2012-2013, a comprehensive liver assessment was conducted to estimate the prevalence of severe liver disease.

Results

405 chronic carriers (95\% genotype E), recruited at a median age of 10.8 years, were followed for a median length of 28.4 years. Annually, 7.4\% (95\% CI: 6.3-8.8\%) cleared $\mathrm{HBeAg}$ and $1.0 \%(0.8-1.2 \%)$ cleared HBsAg. The incidence of HCC was 55.5/100,000 carrier-years $(95 \%$ 
CI: 24.9-123.5). In the 2012-2013 survey ( $\mathrm{n}=301)$, 5.5\% (95\% CI: $3.4-9.0 \%)$ had significant liver fibrosis. HBV genotype A (versus E), chronic aflatoxin B1 exposure, and an HBsAgpositive mother, a proxy for mother-to-infant transmission, were risk factors for liver fibrosis. A small proportion $(16.0 \%)$ of chronic carriers were infected via mother-to-infant transmission, however, this population represented a large proportion $(63.0 \%)$ of the cases requiring antiviral therapy.

Conclusions

The incidence of HCC amongst chronic HBV carriers in West Africa was higher than that in Europe but lower than rates in East Asia. High risk of severe liver disease amongst the few who are infected by their mothers underlines the importance of interrupting perinatal transmission in sub-Saharan Africa.

\section{Summary Box}

What is already known about this subject?

- Chronic hepatitis B virus infection is a common cause of liver disease in sub-Saharan Africa. 
1

2

3

4

5

- Although the WHO recently published its first HBV treatment guidelines with a main focus on resource-limited countries, their recommendations are based on Western and Asian studies, since there have been no natural history data from sub-Saharan Africa.

- Mother-to-infant transmission is a risk factor for chronic HBV infection, however, it is unclear whether this mode of transmission further increases the risk of severe liver disease in chronic carriers.

What are the new findings?

- The incidence rate of hepatocellular carcinoma (HCC) in treatment-naïve male chronic HBV carriers in The Gambia was higher than Europe but lower than in East Asia.

- Mother-to-infant transmission was a risk factor for persistent viral replication, elevated transaminase, significant fibrosis and HCC.

- The majority (63.0\%) of cases requiring antiviral therapy were attributable to maternal transmission.

- Among chronic HBV carriers, genotype A (versus E) and chronic exposure to aflatoxin B1 were associated with an elevated risk of significant liver fibrosis.

How might it impact on clinical practice in foreseeable future?

- The disproportionate risk of severe liver disease amongst people who acquired HBV from their mothers emphasizes the importance of interrupting perinatal transmission in sub-Saharan Africa. 


\section{INTRODUCTION}

In sub-Saharan Africa (SSA) chronic hepatitis B virus (HBV) infection is a major public health problem, which causes an estimated 61,000 deaths due to cirrhosis or hepatocellular carcinoma (HCC) each year [1]. Before the introduction of hepatitis B vaccine, $>70 \%$ of African children were exposed to HBV at birth or during childhood and $10-20 \%$ became chronic HBV carriers [2]. Currently, all African countries have integrated hepatitis B vaccine into their Expanded Program on Immunization (EPI).

Despite its efficacy in preventing chronic HBV infection, vaccination has several limitations as a control strategy. First, a large number of people who were infected prior to the vaccination programs are left with chronic HBV infection [3]. Second, hepatitis B vaccine does not always prevent mother-to-infant transmission [4], especially when the vaccine is not given at birth [5]. Though this mode of transmission is less frequent than horizontal transmission in SSA [6], the risk of HCC may be higher in vertically-transmitted chronic infections [7-9].

To overcome these limitations, antiviral therapy can be used to prevent HBV-related disease in cases of chronic HBV infection and also to prevent vertical HBV transmission. In March 2015, the World Health Organization (WHO) issued its first guidelines on chronic HBV infection to improve access to antiviral therapy in low- and middle-income countries. However, their recommendations are based on the findings from Asia, Europe and North America, since there have been no natural history data from SSA [3]. Understanding the natural history of chronic HBV infection is essential to inform decisions about who to treat and when to treat [3]. 
The UK Medical Research Council (MRC), the International Agency for Research on Cancer (IARC/WHO) and the Gambia Government have been supporting studies on HBV infection in The Gambia since the 1980's, and have established a population-based open cohort of treatment-naïve chronic HBV carriers. We used this cohort to describe the natural history of chronic HBV infection: i) the sero-clearance rates of hepatitis $\mathrm{B}$ e antigen $(\mathrm{HBeAg})$ and surface antigen (HBsAg); ii) the incidence of HCC, end-stage liver disease (ESLD) and allcause mortality; iii) longitudinal changes in serum HBV DNA and alanine transaminase (ALT) levels; and iv) the prevalence of significant liver fibrosis and chronic liver disease requiring antiviral therapy according to the European Association for the Study of the Liver (EASL) [10] or the WHO guidelines [3]. We also estimated the HBV-related disease burden attributable to the mother-to-infant transmission in SSA by examining the associations between these outcomes and maternal HBsAg, a proxy for mother-to-infant HBV transmission [8].

\section{METHODS}

\section{Participants}

The cohort of chronic HBV carriers was recruited from Keneba and Manduar, two neighboring villages in West Kiang District. They are typical of many African rural communities where Mandinka and Jola people live in mud or lath-and-plaster houses roofed with thatch or corrugated iron with subsistence agriculture [11]. Primary health care has been available free of charge at the MRC Keneba Clinic. Baseline HBV sero-surveys were undertaken in 1974 and in 1980. In the first survey the entire population was surveyed $(\mathrm{n}=1,317)$ and $13.2 \%$ were found to carry HBsAg [11] while the second survey was limited to 
children aged $<15$ years and their mothers $(n=802)$ [12]. Following the third sero-survey in 1984 [13], all non-immune children in Keneba/Manduar were invited to participate in an HBV vaccine trial [14]. Hepatitis B vaccination was introduced in the EPI in 1990 with a vaccine schedule starting at birth. Hepatitis B immunoglobulin has been unavailable. Between 1985 and 2008, sero-surveys to measure the vaccine efficacy were repeated every 4-5 years [4,14-17]. In parallel, those who had been tested HBsAg-positive were followed for HBV sero-markers in 1985, 1989, 1992, 1993, 1998, 2003, and 2008 (supplementary table 1). Survey participation was $92-100 \%$ and $50-85 \%$ in those aged $0-9$ and $10-19$ years, respectively [12-15].

\section{Liver assessment in 2012-2013}

Following community approval, people with chronic HBV infection in the cohort were invited to a liver assessment as part of the PROLIFICA (Prevention of Liver Fibrosis and Cancer in Africa) project [18]. Chronic infection was defined as serum HBsAg positivity at two visits at least six months apart. In individuals aged $\geq 13$ years, HBsAg positivity at only one visit was considered as chronic infection because, in the pre-vaccination era, $90 \%$ of children in Keneba/Manduar acquired the infection by the age of 13 years and new infections were uncommon beyond this age [13]. After written informed consent, participants, who had fasted overnight, underwent a standardized clinical examination that involved blood collection, abdominal ultrasound and liver stiffness measurement using transient elastography (Fibroscan, Echosens, France). Those with serum HBV DNA $\geq 2,000 \mathrm{IU} / \mathrm{ml}$ or liver stiffness $\geq 6.5 \mathrm{kPa}$ or ALT $\geq 40$ IU/L, were invited for liver biopsy. Histopathologists in UK scored liver fibrosis using Metavir system [19]. The study was approved by the Gambia Government/MRC Joint Ethics Committee and conducted according to the guidelines of the Declaration of Helsinki. 


\section{Laboratory assays}

HBsAg was detected by radioimmunoassay (Ausria-I, Abbott, USA) in 1974 [12], reverse passive hemagglutination assay (Wellcotest, Wellcome Diagnostics, UK) in 1980-1998 [15], immunochromatography (Determine, Abbott) in 2003-2008 [20], and chemiluminescent microparticle immunoassay (Architect, Abbott) in 2012-2013 [21]. HBsAg-positive samples were tested for HBeAg by radioimmunoassay in 1980-1998 [15] and later by enzyme immunoassay (EIA) (Diasorin, Biomedica, Italy) [20]. The serological tests were strongly correlated with one another [20,21]. HBV DNA levels were measured at the end of the study in stored samples collected in 1984, 1989, 1993, 2003, 2008, and 2012-2013, using in-house quantitative real-time polymerase chain reaction (detection limit: $50 \mathrm{IU} / \mathrm{ml}$ ), calibrated against an international standard [22]. As previously reported, samples collected in 2003 were examined for $\mathrm{HBV}$ genotype and an $\mathrm{AGG} \rightarrow \mathrm{AGT}$ mutation at codon 249 of p53 tumor suppressor gene (p53R249S) in cell-free DNA, a biomarker of chronic aflatoxin B1 exposure [23]. Samples collected in 2012-2013 were tested for alpha-fetoprotein and antibodies to Hepatitis C virus (HCV) using microparticle EIA (AxSYM, Abbott), antibodies to Hepatitis D virus (HDV) using EIA (ETI-AB-DELTAK-2, Diasorin), and antibodies to HIV-1/2 and p24 antigen using EIA (Genscreen-ULTRA, Bio-Rad, USA). Schistosoma mansoni infection is rare in The Gambia [24] and therefore was not investigated.

\section{Ascertainment of liver disease and death}

Significant liver fibrosis, severe fibrosis and cirrhosis was defined as $\geq F 2, \geq F 3$ and $F 4$ (Metavir) for those who had liver histopathology and liver stiffness $\geq 7.9, \geq 8.2$ and $\geq 9.5 \mathrm{kPa}$ for those without biopsy. These cut-offs were determined by our validation study in The 
Gambia, where the sensitivity of Fibroscan to predict $\geq F 2$ was $81 \%$ and the specificity was $81 \%$ [25]. The EASL criteria for antiviral therapy are: i) viral load $\geq 2,000 \mathrm{IU} / \mathrm{ml}$ and significant fibrosis, or ii) viral load $\geq 2,000 \mathrm{IU} / \mathrm{ml}$ and moderate/severe active necroinflammation $(\geq \mathrm{A} 2$ by Metavir activity grade), or iii) viral load $\geq 20,000 \mathrm{IU} / \mathrm{ml}$ and $\mathrm{ALT} \geq 80 \mathrm{IU} / \mathrm{L}$, or iv) detectable viral load and cirrhosis [10]. The WHO criteria are: i) clinically diagnosed cirrhosis, or ii) aspartate transaminase (AST)-to-platelet ratio index (APRI) $>2.0$, or iii) $\geq 30$ years old and abnormal ALT and HBV DNA $>20,000 \mathrm{IU} / \mathrm{ml}$ [3]. The phases of the natural history of chronic HBV infection were described [10,26] for the baseline and 2012-2013 survey (supplementary table 2).

HCC cases were identified through a follow-up examination, review of medical records in the MRC Keneba Clinic, or by data linkage with the Gambia National Cancer Registry [27]. The diagnosis was based on the identification of a focal hepatic lesion consistent with HCC on the ultrasound and elevated serum alpha-fetoprotein ( $\geq 200 \mathrm{ng} / \mathrm{ml}$ ). ESLD includes HCC and nonmalignant ESLD. The latter was defined as cirrhosis without HCC and the presence of ascites, hepatic encephalopathy, or hematemesis. The date of death was ascertained through a review of the medical chart in the MRC or data linkage with the West Kiang Demographic Surveillance System [28].

\section{Statistical analyses}

The person-years of follow-up for $\mathrm{HBeAg} / \mathrm{HBsAg}$ clearance, HCC, ESLD, or death were calculated from the date they were identified as HBsAg-positive to the date of endpoint or last follow-up, whichever came first. The date of sero-clearance was defined as the midpoint between the last positive and the first negative result. The cumulative incidence was estimated 
as a function of age using the Kaplan-Meier Method. Age was used rather than time since entry into the study because most infections occur during early childhood [13], and therefore age approximates the duration of $\mathrm{HBV}$ infection. The associations between maternal $\mathrm{HBsAg}$, as recorded at the recruitment of the child, and the $\mathrm{HBeAg} / \mathrm{HBsAg}$ loss were examined using Poisson regression with robust standard error to account for clustering in children that share the same mother. The models included current age, calendar year, sex, and birthplace as covariates. The effect of maternal HBsAg on ALT and HBV DNA ( $\log _{10}$ transformed) was quantified using a linear mixed model with random intercept and random slope to account for the multiple measurements made on the same individuals over time. The detection limit of the assay was assigned to samples with undetectable viral load. The effect of maternal HBsAg on significant fibrosis and meeting antiviral treatment criteria was estimated using logistic regression to control for age, sex, and birthplace (partial model), and additionally for HBV genotype and p53R249S (full model).

Population attributable fractions were calculated [29] for the effects of maternal sero-status on chronic HBV infection and HBV-related liver disease (significant fibrosis and meeting the EASL treatment criteria). This analysis included all the survey participants (1974-2008) with available maternal sero-status who did not receive hepatitis B vaccine. It was not restricted to chronic carriers so that the twofold effect of mother-to-infant transmission could be estimated, i.e., the increased risk of both chronic infection [30], and of liver disease progression in those with established chronic infection [8,9]. All analyses were performed using STATA 11.0 (Stata Corporation, USA). 


\section{RESULTS}

\section{Baseline characteristics}

Between 1974 and 2008, 551 villagers tested positive for HBsAg at least once in the Keneba/Manduar sero-surveys. None had HCC at enrolment. Twenty-nine HBsAg-positive villagers did not participate in any subsequent sero-surveys. These individuals did not differ from the rest of HBsAg-positive individuals in sex, age, HBeAg, HBV DNA and ALT levels at baseline. Finally, there were 405 chronic carriers (figure 1). The median length of followup was 28.4 years (IQR: 17.7-32.7) with the median number of six sero-surveys (IQR: 3-8). The median age at recruitment was 10.8 years (IQR: 4.6-21.8). Half were male, and 65.2\%, $26.1 \%$, and $8.7 \%$ had a mother who was HBsAg-negative, HBsAg-positive/HBeAg-negative, and HBsAg-positive/HBeAg-positive, respectively (table 1). The children of positive mothers had high viral load $(\mathrm{p}=0.04)$ and abnormal ALT levels $(\mathrm{p}=0.05)$ at baseline. Thirty became chronic carriers despite having been fully vaccinated against HBV; median age at the first vaccine was 34 days and none received within three days of birth, and the majority $(60.9 \%$, 14/23) had HBsAg-positive mothers. In the 2003 sero-survey, 95.1\% (97/102) had genotype E and the rest genotype A; 44.2\% (100/226) had the p53R249S mutation [23]. 
Table 1. Baseline characteristics of people with chronic HBV infection by maternal HBsAg status $(\mathrm{N}=405)$

\begin{tabular}{|c|c|c|c|c|c|c|}
\hline \multicolumn{2}{|l|}{ Variables } & All $(\mathrm{N}=405)$ & $\begin{array}{l}\text { Unknown } \\
\text { maternal } \\
\text { sero-status } \\
(\mathrm{n}=152)\end{array}$ & $\begin{array}{l}\text { With } \\
\text { HBsAg(+) } \\
\text { mother } \\
(\mathrm{n}=88)\end{array}$ & $\begin{array}{l}\text { With } \\
\text { HBsAg(-) } \\
\text { mother } \\
(\mathrm{n}=165)\end{array}$ & $\begin{array}{l}\text { p- } \\
\text { value }^{1}\end{array}$ \\
\hline \multirow[t]{2}{*}{ Sex } & Male & $204(50 \%)$ & $63(41 \%)$ & $48(55 \%)$ & $93(56 \%)$ & 0.8 \\
\hline & Female & $201(50 \%)$ & $89(59 \%)$ & $40(45 \%)$ & $72(44 \%)$ & \\
\hline \multirow{5}{*}{$\begin{array}{l}\text { Age group } \\
\text { (years) }\end{array}$} & $<5$ & $109(27 \%)$ & $4(3 \%)$ & $42(48 \%)$ & $63(38 \%)$ & $0.9^{2}$ \\
\hline & $5-9$ & $83(20 \%)$ & $9(6 \%)$ & $22(25 \%)$ & $52(32 \%)$ & \\
\hline & $10-14$ & $56(14 \%)$ & $16(10 \%)$ & $8(9 \%)$ & $32(19 \%)$ & \\
\hline & $15-19$ & $39(10 \%)$ & $23(15 \%)$ & $5(6 \%)$ & $11(7 \%)$ & \\
\hline & $\geq 20$ & $118(29 \%)$ & $100(66 \%)$ & $11(12 \%)$ & $7(4 \%)$ & \\
\hline \multirow[t]{2}{*}{ Birth place } & Keneba & $233(58 \%)$ & $106(70 \%)$ & $39(44 \%)$ & $88(53 \%)$ & 0.4 \\
\hline & Manduar & $172(42 \%)$ & $46(30 \%)$ & $49(56 \%)$ & $77(47 \%)$ & \\
\hline \multirow{2}{*}{$\begin{array}{l}\text { Hepatitis } \\
\text { B vaccine }\end{array}$} & Never & $375(93 \%)$ & $145(95 \%)$ & $74(84 \%)$ & $156(95 \%)$ & 0.02 \\
\hline & Ever & $30(7 \%)$ & $7(5 \%)$ & $14(16 \%)$ & $9(5 \%)$ & \\
\hline \multirow[t]{2}{*}{$\mathrm{HBeAg}$} & Negative & $213(55 \%)$ & $118(86 \%)$ & $30(34 \%)$ & $65(40 \%)$ & 0.4 \\
\hline & Positive & $173(45 \%)$ & $19(14 \%)$ & $58(66 \%)$ & $96(60 \%)$ & \\
\hline \multirow{3}{*}{$\begin{array}{l}\text { HBV } \\
\text { DNA } \\
(\mathrm{IU} / \mathrm{ml})\end{array}$} & $<2,000$ & $222(57 \%)$ & $121(83 \%)$ & $30(35 \%)$ & $71(45 \%)$ & $0.04^{2}$ \\
\hline & $2,000-10^{8}$ & $90(23 \%)$ & $20(14 \%)$ & $19(22 \%)$ & $51(32 \%)$ & \\
\hline & $\geq 10^{8}$ & $79(20 \%)$ & $5(3 \%)$ & $37(43 \%)$ & $37(23 \%)$ & \\
\hline \multirow{2}{*}{$\begin{array}{l}\text { ALT } \\
(\mathrm{IU} / \mathrm{L})\end{array}$} & $<40$ & $367(94 \%)$ & $134(92 \%)$ & $77(91 \%)$ & $156(97 \%)$ & 0.05 \\
\hline & $\geq 40$ & $25(6 \%)$ & $12(8 \%)$ & $8(9 \%)$ & $5(3 \%)$ & \\
\hline \multirow{5}{*}{$\begin{array}{l}\text { Phase of } \\
\text { natural } \\
\text { history }\end{array}$} & $\begin{array}{l}\text { Immune } \\
\text { tolerant }\end{array}$ & $116(29 \%)$ & $8(5 \%)$ & $42(48 \%)$ & $66(40 \%)$ & 0.1 \\
\hline & $\begin{array}{l}\mathrm{HBeAg}(+) \\
\text { chronic } \\
\text { hepatitis }\end{array}$ & $14(3 \%)$ & $5(3 \%)$ & $7(8 \%)$ & $2(1 \%)$ & \\
\hline & $\begin{array}{l}\mathrm{HBe} A g(-) \\
\text { chronic } \\
\text { hepatitis }\end{array}$ & $11(3 \%)$ & $7(5 \%)$ & $1(1 \%)$ & $3(2 \%)$ & \\
\hline & Inactive carrier & $190(47 \%)$ & $117(77 \%)$ & $22(25 \%)$ & $51(31 \%)$ & \\
\hline & Unclassified & $74(18 \%)$ & $15(10 \%)$ & $16(18 \%)$ & $43(26 \%)$ & \\
\hline \multirow{2}{*}{$\begin{array}{l}\text { HBV } \\
\text { genotype }^{3}\end{array}$} & Genotype A & $5(5 \%)$ & $1(3 \%)$ & $2(8 \%)$ & $2(5 \%)$ & 0.6 \\
\hline & Genotype E & $97(95 \%)$ & $33(97 \%)$ & $24(92 \%)$ & $40(95 \%)$ & \\
\hline \multirow{2}{*}{$\begin{array}{l}\text { p53R249S } \\
\text { mutation }^{3}\end{array}$} & Negative & $126(56 \%)$ & $50(63 \%)$ & $23(44 \%)$ & $53(56 \%)$ & 0.1 \\
\hline & Positive & $100(44 \%)$ & $30(37 \%)$ & $29(56 \%)$ & $41(44 \%)$ & \\
\hline \multicolumn{2}{|c|}{$\begin{array}{l}\text { Median no. of follow-up } \\
\text { sero-surveys (IQR) }\end{array}$} & $6(3,8)$ & $4(3,6)$ & $6(4,8)$ & $7(5,8)$ & 0.1 \\
\hline \multicolumn{2}{|c|}{$\begin{array}{l}\text { Median years of follow-up } \\
\text { (IQR) }\end{array}$} & $\begin{array}{l}28.4(17.7, \\
32.7)\end{array}$ & $\begin{array}{l}24.4(10.2, \\
37.9)\end{array}$ & $\begin{array}{l}28.6(16.0, \\
32.0)\end{array}$ & $\begin{array}{l}28.7(23.8, \\
32.1)\end{array}$ & 0.2 \\
\hline
\end{tabular}

${ }^{1}$ Comparison was made between participants with HBsAg-positive mothers and HBsAgnegative mothers. P-value and 95\% CI were obtained by Wald test with robust standard error.

${ }^{2}$ Linear test for trend

${ }^{3}$ Determined in a subset of participants in 2003 


\section{HBeAg sero-clearance}

At the enrolment, $213(52.6 \%)$ chronic carriers had already lost $\mathrm{HBeAg}$, The age-specific prevalence of $\mathrm{HBeAg}$ at baseline decreased with increasing age (supplementary figure 1). Of the $173 \mathrm{HBeAg-positive} \mathrm{carriers} \mathrm{at} \mathrm{baseline,} 82.1 \%$ lost $\mathrm{HBeAg}$ and the clearance rate was 7.4\%/year (95\% CI: 6.3-8.8) (table 2, figure 2). Fifteen experienced HBeAg reversion, nine of whom eventually lost $\mathrm{HBeAg}$ whilst six continued to carry $\mathrm{HBeAg}$ until the last follow-up. After adjusting for sex, current age, calendar year and birthplace, the sero-clearance rate was slower in carriers with high HBV DNA levels $\left(\geq 10^{8} \mathrm{IU} / \mathrm{ml}\right)$ at baseline (supplementary table 3). Carriers with HBsAg-positive mothers tend to clear HBeAg slowly, although this did not reach statistical significance (supplementary figure 2-A). 
Table 2. Incidence rates of $\mathrm{HBeAg}$ and HBsAg sero-clearance, HCC, ESLD and all-cause mortality in people with chronic HBV infection by gender

\begin{tabular}{|l|c|c|c|c|c|}
\hline Event & $\begin{array}{l}\text { No. of } \\
\text { subjects }\end{array}$ & $\begin{array}{l}\text { Person-years } \\
\text { at risk }\end{array}$ & $\begin{array}{l}\text { No. of } \\
\text { events }\end{array}$ & Rate & $95 \%$ CI \\
\hline HBeAg clearance & 173 & 1912 & 142 & $7.4 / 100$ & $6.3-8.8$ \\
\hline Male & 109 & 1231 & 86 & 7.0 & $5.7-8.6$ \\
\hline Female & 64 & 681 & 56 & 8.2 & $6.3-10.7$ \\
\hline HBsAg clearance & 405 & 8502 & 85 & $1.00 / 100$ & $0.81-1.24$ \\
\hline Male & 204 & 4076 & 32 & 0.79 & $0.56-1.11$ \\
\hline Female & 201 & 4426 & 53 & 1.20 & $0.91-1.57$ \\
\hline HCC & 405 & 10815 & 6 & $55.5 / 100,000$ & $24.9-123.5$ \\
\hline Male & 204 & 5200 & 6 & 115.4 & $51.8-256.8$ \\
\hline Boys (<20 y.o.) & & 1930 & 0 & 0.0 & N/A \\
\hline Adult men ( $\geq 20$ y.o.) & & 3270 & 6 & 183.5 & $82.4-408.5$ \\
\hline Female & 201 & 5615 & 0 & 0.0 & N/A \\
\hline ESLD (including HCC) & 405 & 10815 & 8 & $74.0 / 100,000$ & $37.0-147.9$ \\
\hline Male & 204 & 5200 & 7 & 134.6 & $64.2-282.4$ \\
\hline Female & 201 & 5615 & 1 & 17.8 & $2.5-126.4$ \\
\hline All-cause mortality & 405 & 10815 & 43 & $397.6 / 100,000$ & $294.9-536.1$ \\
\hline Male & 204 & 5200 & 25 & 480.8 & $324.9-711.5$ \\
\hline Female & 201 & 5615 & 18 & 320.6 & $202.0-508.8$ \\
\hline
\end{tabular}




\section{HBsAg sero-clearance}

The rate of HBsAg sero-clearance was 1.0\%/year (95\% CI: 0.8-1.2) (table 2) with half clearing by 57 years old (figure 2). Younger age and high HBV DNA levels at baseline were associated with delayed HBsAg sero-clearance (supplementary table 4). The sero-clearance rate was slower in carriers with HbsAg-positive mothers, but this was not statistically significant (supplementary figure 2-B).

\section{HCC, ESLD, and mortality}

Of the 405 chronic carriers, 43 died; the all-cause mortality rate was $397.6 / 100,000$ personyears (95\% CI: 294.9-536.1). The most common cause of death was HCC (24.0\%) in men and bacterial infection $(22.2 \%)$ in women. All patients with ESLD (including HCC $(n=6)$ and non-malignant $\operatorname{ESLD}(\mathrm{n}=2)$ ) died within one year of diagnosis. Incidence rates of HCC and ESLD were 55.5 (95\% CI: 24.9-123.5) and 74.0 (95\% CI: 37.0-147.9) per 100,000 personyears, respectively (table 2). All HCC patients were men, all but one was HBeAg-negative at enrolment, and their age at diagnosis ranged between 38 and 67 years (supplementary table 5). The HCC incidence in men $\geq 20$ years was 183.5 (95\% CI: $82.4-408.5)$ per 100,000 personyears. Maternal sero-status was available in three ESLD patients, and all had HBsAg-positive mothers. Crude incidence rates of HCC in carriers with HBsAg-positive mothers was 89.2/100,000 (95\% CI: 22.3-356.8) while those with negative mothers was $0 / 100,000$ (unadjusted $\mathrm{p}<0.001$ ).

\section{Mean HBV DNA and ALT over time}


The trajectories of HBV DNA and ALT levels by maternal HBsAg are presented in figure 3. Viral load decreased with increasing age at measurement whilst ALT increased. Both viral load and ALT were higher in men than women (supplementary table 6). After adjusting for confounders, the geometric mean viral load was 4.7 times higher $(95 \% \mathrm{CI}: 2.0-11.1, \mathrm{p}<0.001)$ and mean ALT was $4.0 \mathrm{IU} / \mathrm{L}$ higher $(95 \% \mathrm{CI}: 1.2-6.8, \mathrm{p}=0.005)$ in carriers with HBsAgpositive mothers than in those with HBsAg-negative mothers.

\section{Prevalence of chronic liver disease in 2012-2013}

After excluding those who died, 83.1\% (301/362) of chronic HBV carriers participated in the liver assessment in 2012-2013 (figure 1). Participation was lower in men than women, in younger than in older age groups and in carriers with positive $\mathrm{HBeAg}$ at baseline compared with those HBeAg-negative. Table 3 presents the characteristics of the participants. None had ever received antiviral or immunosuppressive therapy. The number co-infected with HIV, $\mathrm{HCV}$, and HDV was three, one, and one, respectively. None had alcohol intake $>20 \mathrm{~g} /$ day based on the standardized questionnaire. Between the baseline and 2012-2013 survey, the proportion of carriers in the immune tolerant phase decreased from $28.6 \%$ to $2.3 \%$ whilst the proportion in the inactive phase increased from $46.9 \%$ to $64.5 \%$ (tables 1 and 3, supplementary figure 3). Only 6.3\% were in HBeAg-negative chronic hepatitis in 2012-2013. Thirty participants had a liver biopsy and 269 had a valid measurement using transient elastography. No liver specimen had steatosis. Fifteen carriers (5.5\%, 95\% CI: 3.4-9.0\%) had significant fibrosis, including nine with severe fibrosis and one with cirrhosis. After controlling for confounders, male gender, genotype A, p53R249S mutation, persistence of HBeAg, high viral load, and ALT were risk factors for significant fibrosis (table 4). After adjusting for sex, age, birthplace, HBV genotype and p53R249S, the odds ratio (OR) for the 
effect of maternal HBsAg on significant fibrosis was 15.8 (95\% CI: 1.4-174.1, p=0.02). Eleven participants $(3.7 \%, 95 \%$ CI: $2.0-6.5 \%)$ met the EASL treatment criteria. Carriers with an HBsAg-positive mother, HBeAg persistence, frequent high viral load, and abnormal ALT were more likely to require antiviral therapy (table 4$)$. Only five participants $(1.7 \%, 95 \% \mathrm{CI}$ : $0.7-3.9 \%$ ) fulfilled the WHO treatment criteria. 
Table 3. Characteristics of people with chronic HBV infection who participated in the liver assessment $2012-2013$ by maternal HBsAg status $(\mathrm{N}=301)$

\begin{tabular}{|c|c|c|c|c|c|}
\hline \multicolumn{2}{|l|}{ Variables } & All $(\mathrm{N}=301)$ & $\begin{array}{l}\text { With HBsAg(+) } \\
\text { mother }(n=66)\end{array}$ & $\begin{array}{l}\text { With HBsAg(-) } \\
\text { mother }(n=123)\end{array}$ & $\begin{array}{l}\mathrm{p}- \\
\text { value }^{1}\end{array}$ \\
\hline \multirow[t]{2}{*}{ Sex } & Male & $130(43 \%)$ & $32(48 \%)$ & $59(48 \%)$ & 0.9 \\
\hline & Female & $171(57 \%)$ & $34(52 \%)$ & $64(52 \%)$ & \\
\hline \multirow{4}{*}{$\begin{array}{l}\text { Current } \\
\text { age group } \\
\text { (years) }\end{array}$} & $<30$ & $46(15 \%)$ & $17(26 \%)$ & $18(14 \%)$ & $0.8^{2}$ \\
\hline & $30-39$ & $117(39 \%)$ & $30(45 \%)$ & $66(54 \%)$ & \\
\hline & $40-49$ & $57(19 \%)$ & $8(12 \%)$ & $28(23 \%)$ & \\
\hline & $\geq 50$ & $81(27 \%)$ & $11(17 \%)$ & $11(9 \%)$ & \\
\hline \multirow{2}{*}{$\begin{array}{l}\text { Birth } \\
\text { place }\end{array}$} & Keneba & $178(59 \%)$ & $27(41 \%)$ & $65(53 \%)$ & 0.3 \\
\hline & Manduar & $123(41 \%)$ & $39(59 \%)$ & $58(47 \%)$ & \\
\hline \multirow{2}{*}{$\begin{array}{l}\text { ALT in } \\
2012 / 2013\end{array}$} & $<40 \mathrm{IU} / \mathrm{L}$ & $268(91 \%)$ & $54(84 \%)$ & $110(93 \%)$ & 0.08 \\
\hline & $\geq 40 \mathrm{IU} / \mathrm{L}$ & $25(9 \%)$ & $10(16 \%)$ & $8(7 \%)$ & \\
\hline \multirow{3}{*}{$\begin{array}{l}\text { HBV } \\
\text { marker in } \\
2012 / 2013\end{array}$} & $\operatorname{HBsAg}(+), \operatorname{HBeAg}(+)$ & $14(5 \%)$ & $6(9 \%)$ & $6(5 \%)$ & $0.3^{2}$ \\
\hline & $\mathrm{HBsAg}(+), \operatorname{HBeAg}(-)$ & $227(75 \%)$ & $53(80 \%)$ & $100(81 \%)$ & \\
\hline & HBsAg(-) & $60(20 \%)$ & $7(11 \%)$ & $17(14 \%)$ & \\
\hline \multirow{5}{*}{$\begin{array}{l}\text { HBV } \\
\text { DNA } \\
\text { (IU/ml) in } \\
2012 / 2013\end{array}$} & Undetectable & $135(47 \%)$ & $23(35 \%)$ & $59(50 \%)$ & $0.02^{2}$ \\
\hline & $50-200$ & $65(22 \%)$ & $16(24 \%)$ & $26(22 \%)$ & \\
\hline & $200-2,000$ & $57(20 \%)$ & $13(20 \%)$ & $23(19 \%)$ & \\
\hline & $2,000-20,000$ & $11(4 \%)$ & $4(6 \%)$ & $4(3 \%)$ & \\
\hline & $\geq 20,000$ & $20(7 \%)$ & $10(15 \%)$ & $7(6 \%)$ & \\
\hline \multirow{7}{*}{$\begin{array}{l}\text { Phase of } \\
\text { natural } \\
\text { history in } \\
2012 / 2013\end{array}$} & Immune tolerant & $7(2 \%)$ & $2(3 \%)$ & $4(3 \%)$ & 0.8 \\
\hline & $\begin{array}{l}\mathrm{HBeAg}(+) \text { chronic } \\
\text { hepatitis }\end{array}$ & $4(1 \%)$ & $4(6 \%)$ & $0(0 \%)$ & \\
\hline & $\begin{array}{l}\text { HBeAg(-) chronic } \\
\text { hepatitis }\end{array}$ & $19(6 \%)$ & $6(9 \%)$ & $7(6 \%)$ & \\
\hline & Inactive carrier & $194(65 \%)$ & $41(62 \%)$ & $88(71 \%)$ & \\
\hline & Occult HBV & $12(4 \%)$ & $2(3 \%)$ & $5(4 \%)$ & \\
\hline & Resolved hepatitis B & $48(16 \%)$ & $5(8 \%)$ & $12(10 \%)$ & \\
\hline & Unclassified & $17(6 \%)$ & $6(9 \%)$ & $7(6 \%)$ & \\
\hline
\end{tabular}

${ }^{1}$ p-value from Wald test with robust standard error to take account of clustering among individuals who share the same mother.

${ }^{2}$ Linear test for trend 
Table 4. Factors associated with significant liver fibrosis $(n=271)^{1}$ and condition fulfilling the EASL treatment criteria ( $\left.\mathrm{n}=301\right)$ among people with chronic HBV infection who participated in the liver assessment 2012-13

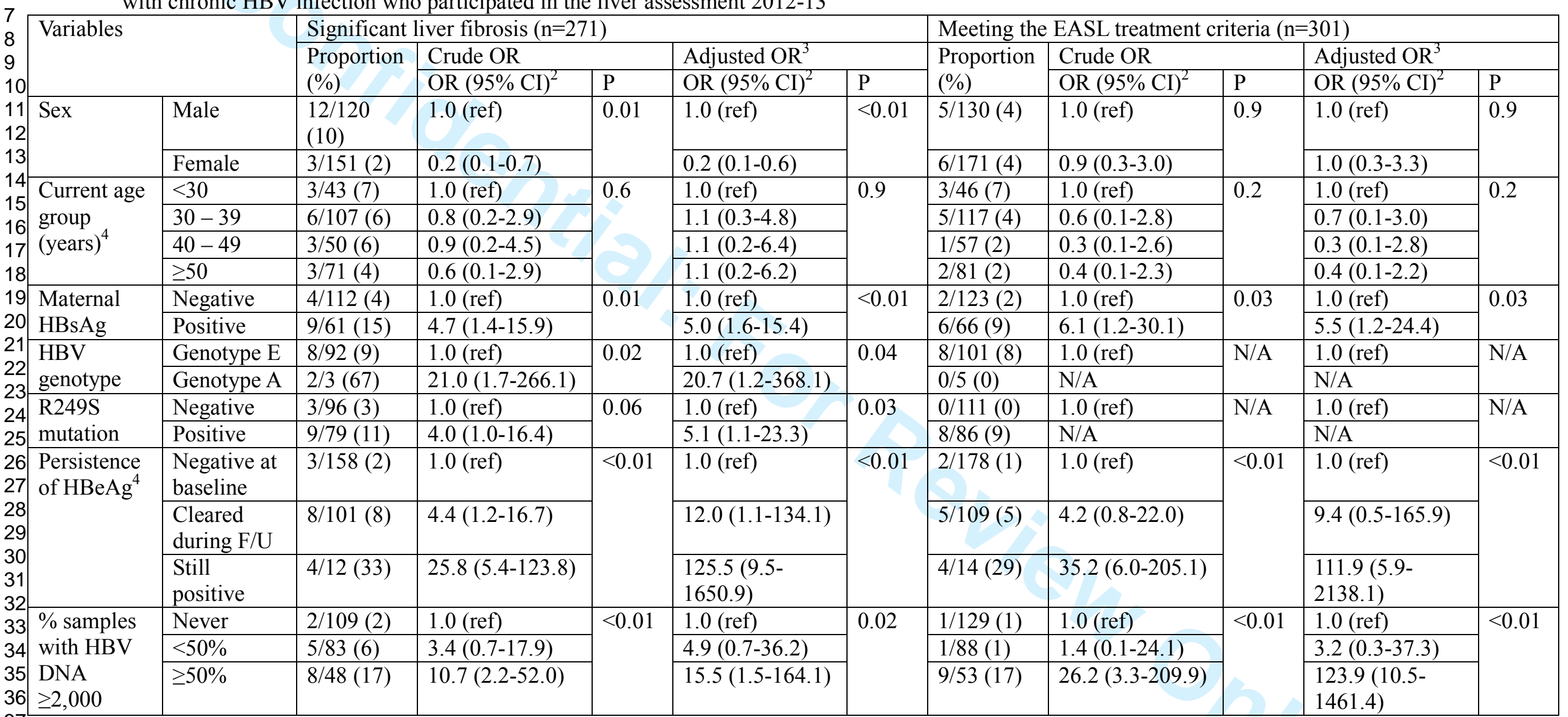




\begin{tabular}{|c|c|c|c|c|c|c|c|c|c|c|c|}
\hline $\mathrm{IU} / \mathrm{ml}^{4,5}$ & 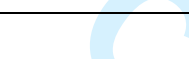 & & & & & & & & & & \\
\hline \multirow{3}{*}{$\begin{array}{l}\text { \% samples } \\
\text { with ALT } \\
\geq 40 \mathrm{IU} / \mathrm{L}^{4,5}\end{array}$} & Never & $5 / 208(2)$ & 1.0 (ref) & \multirow[t]{3}{*}{$<0.01$} & 1.0 (ref) & \multirow[t]{3}{*}{$<0.01$} & $3 / 233(1)$ & 1.0 (ref) & \multirow[t]{3}{*}{$<0.01$} & 1.0 (ref) & \multirow[t]{3}{*}{$<0.01$} \\
\hline & $<50 \%$ & $3 / 14(21)$ & $11.1(2.3-52.5)$ & & $7.7(1.6-36.8)$ & & $2 / 14(14)$ & $12.8(1.9-84.9)$ & & $13.6(1.7-106.5)$ & \\
\hline & $\geq 50 \%$ & $5 / 20(25)$ & $13.5(3.6-50.7)$ & & $17.2(2.5-118.6)$ & & $5 / 23(22)$ & $21.3(4.6-99.3)$ & & $27.6(3.8-200.1)$ & \\
\hline
\end{tabular}

10 Excluding participants who did not have a liver biopsy and who had invalid measurements with transient elastography.

${ }^{2}$ p-value and $95 \%$ CI were obtained by Wald test with robust standard error to take account of clustering among individuals who share the same mother.

${ }^{3}$ OR adjusted for sex, current age and birthplace.

${ }^{4}$ Test for linear trend.

${ }^{5}$ This only includes subjects who had at least two measurements during the follow-up. 


\section{Population attributable fractions}

Maternal sero-status was recorded in 977 unvaccinated participants in Keneba/Manduar between 1974 and 2008, among whom 230 became chronic HBV carriers. The mother was HBsAg-positive in $32.2 \%$ of all the chronic carriers, $64.3 \%$ of carriers with significant fibrosis, and $71.4 \%$ of carriers requiring antiviral treatment according to the EASL guidelines. After controlling for age and sex, having an HBsAg-positive mother was associated with chronic carriage (OR: 2.0, 95\% CI: 1.3-3.1), significant fibrosis (OR: 6.4, 2.1-19.8), and requiring antiviral treatment (OR: $8.5,1.8-40.9)$. Consequently, the population attributable fraction, that is the proportion of chronic carriers attributable to having an HBsAg-positive mother was $16.0 \%(95 \% \mathrm{CI}: 8.6-22.9 \%)$, and the population attributable fractions for HBVrelated significant fibrosis and cases requiring antiviral treatment were 54.3\% (41.5-64.3\%) and $63.0 \%(47.0-74.1 \%)$, respectively.

\section{DISCUSSION}

This is the first long-term follow-up of a population-based cohort of chronic HBV carriers in SSA $[3,31,32]$. We confirmed that the age-standardized rate of $\mathrm{HCC}$ in the chronic carriers in this study $(67.3 / 100,000)$ was much higher than in the general population in The Gambia $(22.1 / 100,000)$ [27], which highlights the importance of controlling chronic HBV infection to prevent HCC. Of note, only $3.7 \%$ and $1.7 \%$ of chronic carriers assessed in 2012-2013 met the EASL and WHO criteria for antiviral treatment, respectively, making HBV a tractable health problem. The PROLIFICA project, the first treatment program for HBV mono-infected 
individuals in SSA, will assess the effectiveness of HBV screening and antiviral therapy in reducing HCC in The Gambia and Senegal.

The incidence rate of HCC in adult men with chronic HBV infection differs considerably by geographical location: 34/100,000 carrier-years in Europe [33], 230/100,000 in Alaska [34], 327/100,000 in New Zealand Maori [35] and 530-880/100,000 in East Asia [36,37]. In SSA, the recorded rates in adult male lie between Europe and Asia $(68.3 / 100,000$ in Senegalese army [36] and 183.5/100,000 in our population-based cohort). These variations in HCC incidence might be partly explained by a difference in the natural history of chronic HBV infection as is discussed below.

It is well established that persistence of high $\mathrm{HBV}$ viral load [37,38] or $\mathrm{HBeAg}$ [39] increases the risk of HCC, and the current study also confirmed an elevated risk of significant fibrosis in carriers with these conditions. In contrast to East Asia where about half of carrier children remain HBeAg-positive into their twenties [40], in SSA, decay of viral replication occurs much faster. We found that half of chronic carriers lost HBeAg by the age of puberty, and amongst those who cleared, the majority became inactive carriers with low or undetectable HBV DNA, and few developed HCC or HBeAg-negative chronic hepatitis.

Another question is what determines the difference in trajectory of viral replication between Asia and SSA. Evans et al. argued that the difference can be explained by the major mode of HBV transmission [36]: in East Asia 40\% of chronic carriers were infected vertically compared with only $10 \%$ in SSA before the introduction of hepatitis B vaccine [6]. In our study we estimated that $16 \%$ of chronic infection attributable to mother-to-infant transmission. 
We found that having an HBsAg-positive mother, which is a proxy for mother-to-infant transmission that occurs perinatally or during early childhood, was a risk factor for maintenance of viremia in The Gambia. Moreover, maternal HBsAg was also associated with high ALT, higher prevalence of significant fibrosis and treatment eligibility, and higher HCC incidence among chronic carriers. By restricting to chronic carriers, our analysis suggests that maternal transmission not only increases the risk of chronic infection [30] but may also further increase the risk of persistent viral replication and severe liver disease [8]. These findings are consistent with previous Asian studies that assessed the effect of maternal HBV status [7,8]. Persistent HBV replication may be facilitated in infants because they have an immature immune system [32].

In the pre-vaccine era, horizontal transmission during childhood was more common than perinatal maternal transmission in SSA, and our data support this $(16.0 \%$ of chronic infection attributable to mother-to-infant transmission). However, we also found that only $3.7 \%$ of chronic carriers required antiviral therapy, and most of these cases $(63.0 \%)$ were attributable to mother-to-infant transmission. This population attributable fraction may even be higher in the post-vaccine era, because the first dose of hepatitis B vaccine is usually delayed for more than one week and therefore perinatal maternal transmission is not well prevented in The Gambia $[4,41,42]$. Indeed, in our cohort, $60.9 \%$ of children who became chronic carriers despite having been fully vaccinated had HBsAg-positive mothers and none received the first vaccine at birth, implying that they were already infected from their mothers before the vaccination.

These findings suggest the importance of interrupting mother-to-infant transmission to reduce the HBV-related disease burden in SSA. Although the WHO recommends a timely 
administration of hepatitis B vaccine within 24 hours of birth to prevent perinatal and early horizontal transmission [3,5], only $11 \%$ of newborns currently receive a birth dose in SSA [43]. This is partly because birth dose is difficult to implement in population where many births take place at home, but also because the Global Alliance for Vaccines and Immunization (GAVI) only provides the pentavalent vaccine (DTP-HepB-Hib), which cannot be used at birth. The feasibility and cost-effectiveness of a timely birth dose vaccine or other strategy (e.g., antiviral therapy for infectious pregnant women) needs to be investigated in SSA [44].

The study is also the first longitudinal cohort to show the association between p53R249S, a marker of chronic aflatoxin exposure, and liver fibrosis. Moreover, we also found a differential risk in liver disease between genotypes $\mathrm{A}$ and $\mathrm{E}$, although the number infected with genotype A was small. In West and Central Africa, genotype E is predominant followed by $\mathrm{A}$, whereas in Asia genotype $\mathrm{C}$ is common [45]. The latter is associated with delayed HBeAg loss compared with genotypes A, B, D, and F [46], and this may explain why persistent viral replication is more common in East Asia than SSA. Unfortunately, a direct comparison of clinical outcomes between genotype $\mathrm{C}$ and $\mathrm{E}$ is difficult because their geographical distributions do not overlap.

The American Guidelines for chronic HBV infection recommend starting the screening for HCC in African HBV carriers at an early age ( $\geq 20$ years old) [26]. This is based on several African case-series where a young median age at HCC diagnosis was reported $[9,47]$. However, of six HCC cases in this study only one $(17 \%)$ was $<40$ years old. This needs to be further studied as this recommendation is costly. 
Our study has several limitations. First, the interval between follow-up sero-surveys (4-5 years) was longer than other longitudinal studies $[34,35,48]$ which might have affected the estimates of $\mathrm{HBeAg} / \mathrm{HBsAg}$ sero-clearance. Nonetheless, the rates are within a range that has been previously reported (HBeAg clearance: 6-9\%/year, HBsAg clearance: $0.5-1.6 \% /$ year) $[34,35,48]$. Second, ideally, we would have used maternal HBeAg status at the birth of the child as a proxy for mother-to-infant transmission, since maternal $\mathrm{HBeAg}$ positivity is a stronger predictor of maternal transmission than HBsAg. However, maternal sero-status was determined when the child entered the cohort, and by this time maternal $\mathrm{HBeAg}$ is likely to have been lost [8]. Third, the phases of the natural history of chronic HBV infection might have been incorrectly classified as they were determined on a single assessment rather than longitudinal monitoring. Fourth, HBV DNA was measured in historical samples, and its levels might have been affected by a prolonged storage and multiple freeze-thaw cycles. Nevertheless, the effect of freeze-thaw cycles is reported to be minimal for HBV DNA assays [49]. Finally, the HCC cases were ascertained through linkage with the cancer registry database, which is estimated to record only $50 \%$ of cases [50]. We attempted to mitigate this bias by also reviewing medical records at the local clinic.

In conclusion, compared to East Asia, the natural history of chronic HBV infection in West Africa is characterized by a shorter duration of viremia and lower incidence of $\mathrm{HCC}$, which is probably due to the lower frequency of mother-to-infant transmission in SSA. Among those who develop severe liver disease in The Gambia the majority are infected by their mothers, emphasizing the importance of interrupting perinatal transmission in SSA. 


\section{ACKNOWLEDGEMENT}

The Gambia Government, MRC and European Commission's Seventh Framework Program (grant 265994) supported the study. We thank Saydiba Tamba, Yaya Minteh and MomodouLamin Jobarteh for fieldwork, Bai-Lamin Dondeh, Safayet Hossin and Tony Fulford for data management, Debbie Garside for study coordination and Pierre Hainaut and Stephanie Villar for the p53R249S mutation study.

\section{COMPETING INTERESTS}

We declare that we have no conflict of interest.

\section{FUNDING}

European Commission’s Seventh Framework Program (grant 265994)

\section{AUTHOR CONTRIBUTIONS}

YS drafted the manuscript, and all the authors reviewed and approved it. HW initiated and MM maintained the cohort. YS, ML, RN, and MTh were responsible for the design of the liver assessment 2012-2013; YS and AJ for fieldwork; ML, GN, and RN for clinical work; HFN and AJB for laboratory assays; RDG for histopathological analysis; YS and CB for statistical analysis. RW, SM, IB, MTa, and UDA supported the conduct of the study. 


\section{REFERENCES}

1 Cowie BC, MacLachlan JH. The global burden of liver disease attributable to hepatitis $\mathrm{B}$, hepatitis $\mathrm{C}$, and alcohol: increasing mortality, differing causes. Hepatology 2013;58:218A - 219A.

2 Kiire CF. The epidemiology and prophylaxis of hepatitis B in sub-Saharan Africa: a view from tropical and subtropical Africa. Gut 1996;38:S5-12.

3 WHO. Guidelines for the prevention, care and treatment of persons with chronic hepatitis B infection. Geneva, Switzerland: 2015.

4 Mendy M, Peterson I, Hossin S, et al. Observational study of vaccine efficacy 24 years after the start of hepatitis B vaccination in two Gambian villages: no need for a booster dose. PLoS One 2013;8:e58029. doi:10.1371/journal.pone.0058029

5 WHO. Hepatitis B vaccines. WHO position paper. Wkly Epidemiol Rec 2009;84:40520 .

6 Edmunds WJ, Medley GF, Nokes DJ, et al. Epidemiological patterns of hepatitis B virus (HBV) in highly endemic areas. Epidemiol Infect 1996;117:313-25.

7 Chang M-H. Natural history and clinical management of chronic hepatitis B virus infection in children. Hepatol Int 2008;2:S28-36.

8 Shimakawa Y, Yan H-J, Tsuchiya N, et al. Association of early age at establishment of chronic hepatitis B infection with persistent viral replication, liver cirrhosis and hepatocellular carcinoma: a systematic review. PLoS One 2013;8:e69430. doi:10.1371/journal.pone.0069430

9 Shimakawa Y, Lemoine M, Bottomley C, et al. Birth order and risk of hepatocellular carcinoma in chronic carriers of hepatitis B virus: a case-control study in The Gambia. Liver Int Published Online First: 26 February 2015. doi:10.1111/liv.12814

10 European Association for the Study of the Liver. EASL clinical practice guidelines: Management of chronic hepatitis B virus infection. J Hepatol 2012;57:167-85. doi:10.1016/j.jhep.2012.02.010

11 McGregor IA. Health and Communicable Disease in a Rural African Environment. Oikos 1976;27:180-92.

12 Whittle HC, Bradley AK, McLauchlan K. Hepatitis B virus infection in two Gambian villages. Lancet 1983;1:1203-6. 
13 Whittle HC, Inskip H, Bradley AK, et al. The Pattern of Childhood Hepatitis B Infection in Two Gambian Villages. J Infect Dis 1990;161:1112-5. doi:10.1093/infdis/161.6.1112

14 Whittle HC, Inskip H, Hall AJ, et al. Vaccination against hepatitis B and protection against chronic viral carriage in The Gambia. Lancet 1991;337:747-50.

15 Whittle HC, Pilkington J, Maine N, et al. Long-term efficacy of continuing hepatitis B vaccination in infancy in two Gambian villages. Lancet 1995;345:1089-92. doi:10.1016/S0140-6736(95)90822-6

16 Whittle HC, Jaffar S, Wansbrough M, et al. Observational study of vaccine efficacy 14 years after trial of hepatitis B vaccination in Gambian children. BMJ 2002;325:569.

17 Van der Sande MAB, Waight P, Mendy M, et al. Long-term protection against carriage of hepatitis B virus after infant vaccination. J Infect Dis 2006;193:1528-35. doi:10.1086/503433

18 Shimakawa Y, Lemoine M, Mendy M, et al. Population-based interventions to reduce the public health burden related with hepatitis B virus infection in The Gambia, West Africa. Trop Med Heal 2014;42:59-64. doi:10.2149/tmh.2014-S08

19 Bedossa P, Poynard T. An algorithm for the grading of activity in chronic hepatitis C. Hepatology 1996;24:289-93. doi:10.1053/jhep.1996.v24.pm0008690394

20 Mendy ME, McConkey SJ, van der Sande MAB, et al. Changes in viral load and HBsAg and HBeAg status with age in HBV chronic carriers in The Gambia. Virol $J$ 2008;5:49. doi:10.1186/1743-422X-5-49

21 Njai HF, Shimakawa Y, Sanneh B, et al. Validation of rapid point-of-care (POC) tests for the detection of hepatitis B surface antigen (HBsAg) in field and laboratory settings in The Gambia, West Africa. J Clin Microbiol 2015;53:1156-63. doi:10.1128/JCM.02980-14

22 Mendy ME, Kaye S, van der Sande M, et al. Application of real-time PCR to quantify hepatitis B virus DNA in chronic carriers in The Gambia. Virol J 2006;3:23. doi:10.1186/1743-422X-3-23

23 Villar S, Le Roux-Goglin E, Gouas DA, et al. Seasonal variation in TP53 R249Smutated serum DNA with aflatoxin exposure and hepatitis B virus infection. Environ Health Perspect 2011;119:1635-40.

24 Schur N, Hürlimann E, Garba A, et al. Geostatistical Model-Based Estimates of Schistosomiasis Prevalence among Individuals Aged 20 Years in West Africa. PLoS Negl Trop Dis 2011;5:e1194. doi:10.1371/journal.pntd.0001194 
25 Lemoine M, Shimakawa Y, Nayagam S, et al. The Gamma-glutamyl transpeptidase to Platelet Ratio (GPR) predicts significant liver fibrosis and cirrhosis in patients with chronic hepatitis B virus infection in West Africa. Gut 2015; in press.

doi:10.1136/gutjnl-2015-309260

26 Lok ASF, McMahon BJ. Chronic hepatitis B: update 2009. Hepatology 2009;50:661-2. doi:10.1002/hep. 23190

27 Bah E, Carrieri MP, Hainaut P, et al. 20-years of population-based cancer registration in hepatitis B and liver cancer prevention in the Gambia, West Africa. PLoS One 2013;8:e75775. doi:10.1371/journal.pone.0075775

28 MRC Unit The Gambia. The West Kiang Demographic Surveillance System (DSS). http://www.mrc.gm/our-research/themes/nutrition/ing-research-areas/west-kiangdemographic-surveillance-system-dss/ (accessed 20 Mar2015).

29 Rothman KJ, Greenland S, Lash TL. Modern Epidemiology. Lippincott Williams \& Wilkins,US 2008.

30 Hyams KC. Risks of Chronicity Following Acute Hepatitis B Virus Infection: A Review. Clin Infect Dis 1995;20:992-1000. doi:10.1093/clinids/20.4.992

31 Lin X, Robinson NJ, Thursz M, et al. Chronic hepatitis B virus infection in the AsiaPacific region and Africa: review of disease progression. $J$ Gastroenterol Hepatol 2005;20:833-43. doi:10.1111/j.1440-1746.2005.03813.x

32 Hadziyannis SJ. Natural history of chronic hepatitis B in Euro-Mediterranean and African countries. J Hepatol 2011;55:183-91. doi:10.1016/j.jhep.2010.12.030

33 Crook PD, Jones ME, Hall AJ. Mortality of hepatitis B surface antigen-positive blood donors in England and Wales. Int J Epidemiol 2003;32:118-24. doi:10.1093/ije/dyg039

34 McMahon BJ, Holck P, Bulkow L, et al. Serologic and clinical outcomes of 1536 Alaska Natives chronically infected with hepatitis B virus. Ann Intern Med 2001;135:759-68.

35 Lim TH, Gane E, Moyes C, et al. Serological and clinical outcomes of horizontally transmitted chronic hepatitis B infection in New Zealand Māori: results from a 28-year follow-up study. Gut 2015;64:966-72. doi:10.1136/gutjnl-2013-306247

36 Evans A, Connell APO, Pugh JC, et al. Geographic variation in viral load among hepatitis B carriers with differing risks of hepatocellular carcinoma. Cancer Epidemiol Biomarkers Prev 1998;7:559-65.

37 Chen CJ, Yang HI, Su J, et al. Risk of hepatocellular carcinoma across a biological gradient of serum hepatitis B virus DNA level. JAMA 2006;295:65-73.

doi:10.1001/jama.295.1.65 
38 Chen $\mathrm{C}$, Lee W, Yang H, et al. Changes in serum levels of HBV DNA and alanine aminotransferase determine risk for hepatocellular carcinoma. Gastroenterology 2011;141:1240-8. doi:10.1053/j.gastro.2011.06.036

39 Chen YC, Chu CM, Liaw YF. Age-specific prognosis following spontaneous hepatitis B e antigen seroconversion in chronic hepatitis B. Hepatology 2010;51:435-44.

40 Chu CM, Liaw YF. Chronic hepatitis B virus infection acquired in childhood: special emphasis on prognostic and therapeutic implication of delayed $\mathrm{HBe} A g$ seroconversion. $J$ Viral Hepat 2007;14:147-52. doi:10.1111/j.1365-2893.2006.00810.x

41 Shimakawa Y, Bottomley C, Njie R, et al. The association between maternal hepatitis $\mathrm{B}$ e antigen status, as a proxy for perinatal transmission, and the risk of hepatitis B e antigenaemia in Gambian children. BMC Public Health 2014;14:532. doi:10.1186/1471-2458-14-532

42 Peto TJ, Mendy ME, Lowe Y, et al. Efficacy and effectiveness of infant vaccination against chronic hepatitis B in the Gambia Hepatitis Intervention Study (1986-90) and in the nationwide immunisation program. BMC Infect Dis 2014;14:7. doi:10.1186/14712334-14-7

43 WHO. Global routine vaccination coverage, 2013. Wkly Epidemiol Rec 2014;89:51722.

44 Howell J, Lemoine M, Thursz M. Prevention of materno-foetal transmission of hepatitis B in sub-Saharan Africa: the evidence, current practice and future challenges. $J$ Viral Hepat 2014;21:381-96. doi:10.1111/jvh.12263

45 Kramvis A, Kew MC. Epidemiology of hepatitis B virus in Africa, its genotypes and clinical associations of genotypes. Hepatol Res 2007;37:S9-19. doi:10.1111/j.1872034X.2007.00098.x

46 Livingston SE, Simonetti JP, Bulkow LR, et al. Clearance of Hepatitis B e Antigen in Patients With Chronic Hepatitis B and Genotypes A, B, C, D, and F. Gastroenterology 2007;133:1452-7.

47 Kew MC, Geddes EW. Hepatocellular carcinoma in rural southern African blacks. Medicine (Baltimore) 1982;61:98-108. doi:10.1097/00005792-198203000-00004

48 Bortolotti F, Guido M, Bartolacci S, et al. Chronic hepatitis B in children after e antigen seroclearance: final report of a 29-year longitudinal study. Hepatology 2006;43:556-62. doi:10.1002/hep.21077

49 Sanlidag T, Akcali S, Ozbakkaloglu B. Serum hepatitis B DNA: Stability in relation to multiple freeze-thaw procedures. $J$ Virol Methods 2005;123:49-52. doi:10.1016/j.jviromet.2004.09.006 
50 Shimakawa Y, Bah E, Wild CP, et al. Evaluation of data quality at the Gambia National Cancer Registry. Int J Cancer 2013;132:658-65. doi:10.1002/ijc. 27646

\section{FIGURE LEGENDS}

Figure 1. Flow diagram of study participants

Figure 2. Proportion of chronic HBV carriers who cleared HBeAg and $\mathrm{HBsAg}$ as a function of age ${ }^{*}$

\footnotetext{
* The number at risk is smaller at 5 and 15 years than at 25 years in the figure for HBsAg because the median age of recruitment was 10.8 years.
}

Figure 3. Changes with age in serum HBV DNA (A) and ALT levels (B) by maternal HBsAg status (- and + denote negative and positive maternal HBsAg, respectively) amongst chronic HBV carriers*

\footnotetext{
${ }^{*}$ Two outliers (ALT: 166 and $351 \mathrm{IU} / \mathrm{L}$ ) in positive maternal HBsAg group are not presented in the figure $3-\mathrm{B}$.
} 


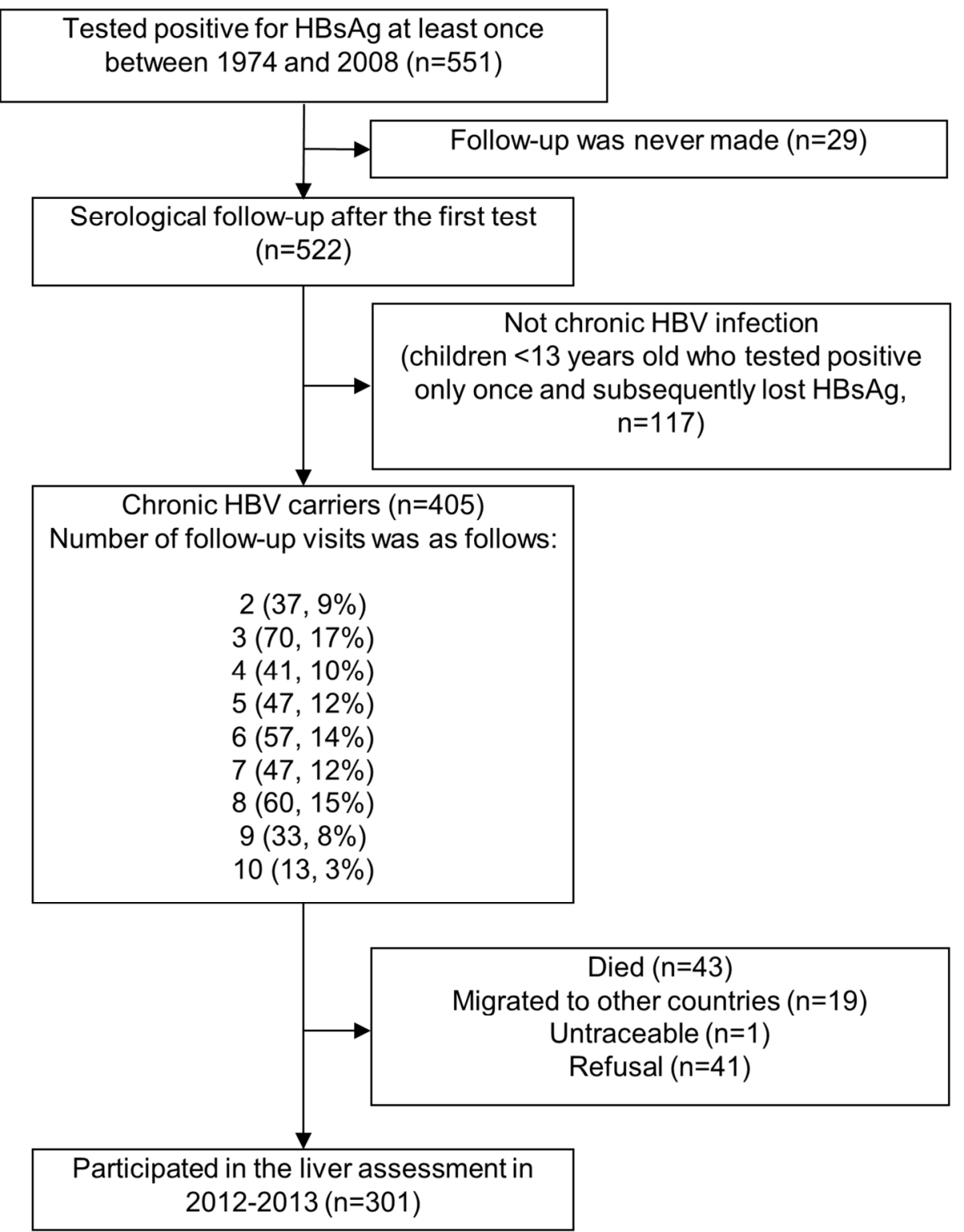

Figure 1. Flow diagram of study participants $159 \times 203 \mathrm{~mm}(300 \times 300 \mathrm{DPI})$ 
Figure 2. Proportion of chronic HBV carriers who cleared HBeAg and HBsAg as a function of age*

* The number at risk is smaller at 5 and 15 years than at 25 years in the figure for HBsAg because the median age of recruitment was 10.8 years.

$$
190 \times 142 \mathrm{~mm}(300 \times 300 \mathrm{DPI})
$$


Figure 3. Changes with age in serum HBV DNA (A) and ALT levels (B) by maternal HBsAg status (- and + denote negative and positive maternal $\mathrm{HBsAg}$, respectively) amongst chronic $\mathrm{HBV}$ carriers* $190 \times 142 \mathrm{~mm}(300 \times 300 \mathrm{DPI})$ 
Figure 3. Changes with age in serum HBV DNA (A) and ALT levels (B) by maternal HBsAg status (- and + denote negative and positive maternal HBsAg, respectively) amongst chronic HBV carriers*

* Two outliers (ALT: 166 and $351 \mathrm{IU} / \mathrm{L}$ ) in positive maternal HBsAg group are not presented in the figure 3B.

$190 \times 142 \mathrm{~mm}(300 \times 300 \mathrm{DPI})$ 
Supplementary Table 1. Participation, numbers who previously tested HBsAg-positive and number of newly identified HBsAg-positive in sero-surveys between 1974 and 2013.

\begin{tabular}{|c|c|c|c|c|c|c|c|c|c|}
\hline \multirow[t]{2}{*}{ Year } & \multirow[t]{2}{*}{ Target population } & \multirow[t]{2}{*}{ Total tested } & \multicolumn{2}{|c|}{$\begin{array}{l}\text { Previously tested } \\
\text { HBsAg-positive }\end{array}$} & \multirow{2}{*}{$\begin{array}{l}\text { Newly } \\
\text { identified in } \\
\text { the current } \\
\text { survey }\end{array}$} & \multicolumn{4}{|c|}{ Laboratory tests performed } \\
\hline & & & Total & $\begin{array}{l}\text { Participated in the } \\
\text { current survey (\% } \\
\text { follow-up) }\end{array}$ & & HBsAg & HBeAg & $\begin{array}{l}\text { HBV } \\
\text { DNA }\end{array}$ & ALT \\
\hline 1974 & All villagers & 1317 & - & - & 136 & RIA & - & - & - \\
\hline 1980 & $\begin{array}{l}\text { Children }<15 \text { years } \& \\
\text { mothers }\end{array}$ & 802 & 136 & $65(48 \%)$ & 104 & RPHA $^{1}$ & RIA & - & - \\
\hline 1984 & Children $<20$ years & 936 & 240 & $99(41 \%)$ & 143 & RPHA $^{1}$ & RIA & q-PCR & Cobas Mira \\
\hline 1985 & Children $<20$ years & 937 & 383 & $242(63 \%)$ & 4 & RPHA $^{1}$ & RIA & - & - \\
\hline 1989 & $\begin{array}{l}\text { Children }<20 \text { years } \& \\
\text { mothers }\end{array}$ & 1358 & 387 & $271(70 \%)$ & 49 & RPHA $^{1}$ & RIA & q-PCR & - \\
\hline 1992 & HBsAg carriers & 366 & 436 & $270(62 \%)$ & 1 & RPHA $^{1}$ & RIA & - & Cobas Mira \\
\hline 1993 & $\begin{array}{l}\text { Children }<20 \text { years } \& \\
\text { mothers }\end{array}$ & 1478 & 437 & $175(40 \%)$ & 30 & RPHA $^{1}$ & RIA & q-PCR & - \\
\hline 1998 & $\begin{array}{l}\text { HBsAg carriers \& } \\
\text { vaccinees }\end{array}$ & 1476 & 467 & $171(37 \%)$ & 12 & RPHA $^{1}$ & RIA & - & - \\
\hline 2003 & All villagers & 1640 & 479 & $294(61 \%)$ & 67 & IC & EIA & q-PCR & - \\
\hline 2008 & $\begin{array}{l}\text { HBsAg carriers \& } \\
\text { vaccinees }\end{array}$ & 2078 & 546 & $323(59 \%)$ & 5 & IC & EIA & q-PCR & $\begin{array}{l}\text { Vitros } \\
\text { DT60-II }\end{array}$ \\
\hline $2012-13$ & Carriers & 332 & 551 & $332(60 \%)$ & 0 & CMIA & EIA & q-PCR & Vitros 350 \\
\hline
\end{tabular}




\begin{abstract}
Abbreviations: CMIA, chemiluminescent microparticle immunoassay; EIA, enzyme immunoassay; IC, immunochromatography; q-PCR, quantitative real-time polymerase chain reaction; RIA, radioimmunoassay; RPHA, reverse passive hemagglutination assay

${ }^{1}$ Positive results using RPHA were confirmed by neutralization with rabbit anti-HBs.
\end{abstract}


Supplementary Table 2. Phases of the natural history of chronic HBV infection (adapted from the EASL/AASLD guidelines)

\begin{tabular}{|l|l|l|l|l|l|}
\hline \multicolumn{2}{|l|}{ Phase } & HBsAg & HBeAg & $\begin{array}{l}\text { HBV DNA } \\
(\mathrm{IU} / \mathrm{ml})\end{array}$ & ALT (U/L) \\
\hline Immune tolerant phase & $\begin{array}{l}\text { HBeAg-positive } \\
\text { chronic hepatitis B }\end{array}$ & Positive & Positive & Any & \\
\hline $\begin{array}{l}\text { Chronic } \\
\text { hepatitis B } \\
\text { disease }\end{array}$ & $\begin{array}{l}\text { HBeAg-negative } \\
\text { chronic hepatitis B }\end{array}$ & Positive & Negative & $\geq 2,000$ & $\geq 40$ \\
\hline Inactive HBV carrier state & & & & $\geq 40$ \\
\hline Occult HBV infection & Positive & Negative & $<2,000$ & \\
\hline Resolved hepatitis B & Negative & Negative & Detectable & Any \\
\hline Unclassified & HBeAg-positive & Positive & Positive & $<20,000$ & $<40$ \\
\cline { 2 - 6 } & HBeAg-negative & Positive & Negative & $\geq 2,000$ & $<40$ \\
\cline { 2 - 6 } & & & & $<2,000$ & $<40$ \\
\hline
\end{tabular}


Supplementary Table 3. Predictors of HBeAg sero-clearance ( $n=173$ )

\begin{tabular}{|c|c|c|c|c|c|c|c|c|}
\hline \multicolumn{2}{|l|}{ Variables } & \multirow{3}{*}{$\begin{array}{l}\text { Person-years } \\
1231 \\
\end{array}$} & \multirow{3}{*}{\begin{tabular}{|l}
$\begin{array}{l}\text { No. of subjects } \\
\text { cleared HBeAg }\end{array}$ \\
86 \\
\end{tabular}} & \multirow{3}{*}{$\begin{array}{l}\begin{array}{l}\text { Rate }(\% \text { per } \\
\text { annum) }\end{array} \\
7.0 \\
\end{array}$} & \multicolumn{2}{|l|}{ Crude RR } & \multicolumn{2}{|l|}{ Adjusted RR ${ }^{3}$} \\
\hline & & & & & \multirow{2}{*}{$\begin{array}{l}\mathbf{R R}(\mathbf{9 5 \%} \mathbf{C I}) \\
1.0 \text { (ref) }\end{array}$} & \multirow{2}{*}{$\begin{array}{l}\text { p-value }^{1} \\
0.3\end{array}$} & \multirow{2}{*}{$\begin{array}{l}\mathbf{R R}(\mathbf{9 5 \%} \mathbf{C I}) \\
1.0 \text { (ref) }\end{array}$} & \multirow{2}{*}{$\begin{array}{l}\text { p-value }^{1} \\
0.3\end{array}$} \\
\hline Sex & Male & & & & & & & \\
\hline & Female & 682 & 56 & 8.2 & $1.2(0.9-1.6)$ & & $1.2(0.9-1.6)$ & \\
\hline \multirow{3}{*}{$\begin{array}{l}\text { Current age } \\
\text { group (years) }\end{array}$} & $0-9$ & 663 & 34 & 5.1 & 1.0 (ref) & 0.02 & 1.0 (ref) & 0.5 \\
\hline & $10-19$ & 761 & 66 & 8.7 & $1.7(1.1-2.5)$ & & $1.4(0.9-2.2)$ & \\
\hline & $\geq 20$ & 488 & 42 & 8.6 & $1.7(1.1-2.6)$ & & $1.2(0.7-1.9)$ & \\
\hline \multirow[t]{2}{*}{ Birthplace } & Keneba & 869 & 67 & 7.7 & 1.0 & 0.6 & 1.0 (ref) & 0.8 \\
\hline & Manduar & 1043 & 75 & 7.2 & $0.9(0.7-1.3)$ & & $1.0(0.7-1.4)$ & \\
\hline \multirow{2}{*}{$\begin{array}{l}\text { Maternal } \\
\text { HBsAg }\end{array}$} & Negative & 1027 & 86 & 8.4 & 1.0 (ref) & 0.1 & 1.0 (ref) & 0.2 \\
\hline & Positive & 673 & 43 & 0 & $0.8(0.5-1.1)$ & & $0.8(0.5-1.2)$ & \\
\hline \multirow{3}{*}{$\begin{array}{l}\text { HBV DNA } \\
(\mathrm{IU} / \mathrm{ml}) \text { at } \\
\text { baseline }^{2}\end{array}$} & $<2,000$ & 333 & 31 & 3 & 1.0 (ref) & 0.009 & 1.0 (ref) & 0.02 \\
\hline & $2,000-10^{8}$ & 601 & 51 & 8.5 & $0.9(0.7-1.2)$ & & $1.0(0.7-1.4)$ & \\
\hline & $\geq 10^{8}$ & 930 & 56 & 6.0 & $0.6(0.5-0.9)$ & & $0.7(0.4-0.9)$ & \\
\hline \multirow{2}{*}{$\begin{array}{l}\text { ALT (IU/L) at } \\
\text { baseline }\end{array}$} & $<40$ & 1736 & 129 & 7.4 & $1.0(\mathrm{ref})$ & 0.9 & 1.0 (ref) & 0.7 \\
\hline & $\geq 40$ & 150 & 11 & 7.3 & $1.0(0.6-1.5)$ & 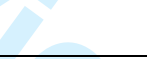 & $0.9(0.6-1.5)$ & \\
\hline
\end{tabular}

${ }^{1} \mathrm{p}$-value and $95 \% \mathrm{CI}$ were obtained by Wald test with robust standard error to take account of clustering among individuals who share the same mother.

${ }^{2}$ Test for linear trend.

${ }^{3}$ Rate ratio adjusted for sex, current age, calendar year and birthplace. 
Supplementary Table 4. Predictors of HBsAg sero-clearance $(n=405)$

\begin{tabular}{|c|c|c|c|c|c|c|c|c|}
\hline \multicolumn{2}{|l|}{ Variables } & \multirow{2}{*}{ Person-years } & \multirow{2}{*}{$\begin{array}{l}\text { No. of subjects } \\
\text { cleared HBsAg }\end{array}$} & \multirow{2}{*}{$\begin{array}{l}\text { Rate (\% per } \\
\text { annum) }\end{array}$} & \multicolumn{2}{|l|}{ Crude RR } & \multicolumn{2}{|l|}{ Adjusted $\mathbf{R R}^{3}$} \\
\hline & & & & & RR $(95 \%$ CI) & p-value ${ }^{1}$ & RR $(95 \%$ CI) & p-value ${ }^{1}$ \\
\hline \multirow[t]{2}{*}{ Sex } & Male & 4076 & 32 & 0.79 & $1.0(\mathrm{ref})$ & 0.05 & 1.0 (ref) & 0.8 \\
\hline & Female & 4426 & 53 & 1.20 & $1.5(1.0-2.3)$ & & $1.1(0.7-1.7)$ & \\
\hline \multirow{6}{*}{$\begin{array}{l}\text { Current age } \\
\text { group (years) }\end{array}$} & $0-9$ & 957 & 1 & 0.10 & 1.0 (ref) & $<0.001$ & 1.0 (ref) & $<0.001$ \\
\hline & $10-19$ & 2189 & 10 & 0.46 & $4.4(0.6-34.1)$ & & $5.5(0.7-42.5)$ & \\
\hline & $20-29$ & 2382 & 24 & 1.01 & $9.6(1.3-71.0)$ & & $16.2(2.2-120.4)$ & \\
\hline & $30-39$ & 1528 & 16 & 1.05 & $10.0(1.3-76.0)$ & & $16.6(2.2-125.9)$ & \\
\hline & $40-49$ & 820 & 19 & 2.32 & $22.2(3.0-165.7)$ & & $35.7(4.8-264.2)$ & \\
\hline & $50-70$ & 627 & 15 & 2.39 & $22.9(3.0-174.6)$ & & $42.5(5.6-321.1)$ & \\
\hline \multirow[t]{2}{*}{ Birthplace } & Keneba & 4344 & 49 & 1.13 & 1.0 (ref) & 0.3 & 1.0 (ref) & 0.3 \\
\hline & Manduar & 4159 & 36 & 0.87 & $0.8(0.5-1.2)$ & & $0.8(0.5-1.2)$ & \\
\hline \multirow{2}{*}{$\begin{array}{l}\text { Maternal } \\
\text { HBsAg }\end{array}$} & Negative & 3913 & 27 & 0.69 & $1.0(\mathrm{ref})$ & 0.1 & 1.0 (ref) & 0.1 \\
\hline & Positive & 2006 & 7 & 0.35 & $0.5(0.2-1.2)$ & & $0.5(0.2-1.2)$ & \\
\hline \multirow{2}{*}{$\begin{array}{l}\text { HBeAg at } \\
\text { baseline }\end{array}$} & Negative & 4353 & 51 & 1.17 & $1.0(\mathrm{ref})$ & $<0.001$ & 1.0 (ref) & 0.3 \\
\hline & Positive & 4000 & 16 & 0.40 & $0.3(0.2-0.6)$ & 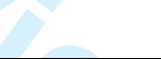 & $0.7(0.3-1.3)$ & \\
\hline \multirow{3}{*}{$\begin{array}{l}\text { HBV DNA } \\
(\mathrm{IU} / \mathrm{ml}) \text { at } \\
\text { baseline }^{2}\end{array}$} & $<2,000$ & 4490 & 68 & 1.52 & 1.0 (ref) & $<0.001$ & 1.0 (ref) & 0.03 \\
\hline & $2,000-10^{8}$ & 2111 & 9 & 0.43 & $0.3(0.1-0.5)$ & & $0.5(0.2-1.0)$ & \\
\hline & $\geq 10^{8}$ & 1776 & 5 & 0.28 & $0.2(0.1-0.4)$ & & $0.4(0.2-1.2)$ & \\
\hline \multirow{2}{*}{$\begin{array}{l}\text { ALT (IU/L) at } \\
\text { baseline }\end{array}$} & $<40$ & 8066 & 79 & 0.98 & 1.0 (ref) & 0.9 & 1.0 (ref) & 1.0 \\
\hline & $\geq 40$ & 339 & 3 & 0.88 & $0.9(0.3-2.9)$ & & $1.0(0.3-3.6)$ & $P$ \\
\hline
\end{tabular}

${ }^{1} \mathrm{p}$-value and $95 \%$ CI were obtained by Wald test with robust standard error to take account of clustering among individuals who share the same mother.

${ }^{2}$ Test for linear trend. 


\footnotetext{
${ }^{3}$ Rate ratio adjusted for sex, current age, calendar year and birthplace.
} 
Supplementary Table 5. Characteristics of individuals who died of ESLD (includes HCC and non-malignant ESLD)

\begin{tabular}{|l|l|l|l|l|l|l|l|l|l|}
\hline Cause of death & $\begin{array}{l}\text { Age at } \\
\text { enrolment }\end{array}$ & $\begin{array}{l}\text { Age at } \\
\text { diagnosis }\end{array}$ & Sex & $\begin{array}{l}\text { Birth } \\
\text { place }\end{array}$ & $\begin{array}{l}\text { Maternal } \\
\text { HBsAg }\end{array}$ & $\begin{array}{l}\text { HBeAg at } \\
\text { baseline }\end{array}$ & $\begin{array}{l}\text { HBV DNA at } \\
\text { baseline (IU/ml) }\end{array}$ & $\begin{array}{l}\text { ALT at } \\
\text { baseline (IU/L) }\end{array}$ & $\begin{array}{l}\text { HBsAg loss during } \\
\text { follow-up }\end{array}$ \\
\hline HCC & 43 & 45 & M & Keneba & N/A & Negative & N/A & N/A & No \\
\hline HCC $^{1}$ & 29 & 67 & M & Manduar & N/A & Negative & 2,800 & 43 & No \\
\hline HCC & 23 & 57 & M & Manduar & N/A & Negative & N/A & 13 & No \\
\hline HCC & 20 & 50 & M & Manduar & Positive & Negative & $1,345,000$ & 10 & No \\
\hline HCC & 21 & 42 & M & Manduar & Positive & Positive & 300,000 & 15 & No \\
\hline HCC & 21 & 38 & M & Manduar & N/A & Negative & N/A & N/A & Yes \\
\hline $\begin{array}{l}\text { Non-malignant } \\
\text { ESLD }\end{array}$ & 21 & 57 & M & Keneba & N/A & Negative & N/A & 6 & No \\
\hline $\begin{array}{l}\text { Non-malignant } \\
\text { ESLD }\end{array}$ & 7 & 19 & F & Keneba & Positive & Positive & N/A & 8 & No \\
\hline
\end{tabular}

${ }^{1}$ This patient had genotype A. 
Supplementary Table 6. Predictors of geometric mean HBV DNA and mean ALT levels $(n=405)$

\begin{tabular}{|c|c|c|c|c|c|c|c|}
\hline \multirow{2}{*}{\multicolumn{2}{|c|}{ Variables }} & \multicolumn{3}{|l|}{ HBV DNA levels } & \multicolumn{3}{|l|}{ ALT levels } \\
\hline & & \multirow{2}{*}{$\begin{array}{l}\text { Geometric mean } \\
\text { HBV DNA (IU/ml) } \\
10,093\end{array}$} & \multirow{2}{*}{$\begin{array}{l}\text { Adjusted ratio of geometric } \\
\text { mean HBV DNA }(95 \% \text { CI) } \\
1.0(\text { ref })\end{array}$} & \multirow{2}{*}{$\begin{array}{l}\text { p-value }{ }^{1} \\
0.04\end{array}$} & \multirow{2}{*}{$\begin{array}{l}\text { Mean ALT } \\
(\text { IU/L) } \\
21.0\end{array}$} & \multirow{2}{*}{$\begin{array}{l}\begin{array}{l}\text { Adjusted mean } \\
\text { difference }(\mathbf{9 5 \%} \mathbf{C I})^{1,3}\end{array} \\
0.0 \text { (ref) }\end{array}$} & \multirow{2}{*}{$\begin{array}{l}\text { p-value } \\
0.01\end{array}$} \\
\hline Sex & Male & & & & & & \\
\hline & Female & 916 & $0.5(0.3-0.7)$ & & 18.7 & $-3.5(-6.3-0.8)$ & \\
\hline \multirow{6}{*}{$\begin{array}{l}\text { Current age } \\
\text { group (years) }\end{array}$} & $0-9$ & $6,505,734$ & 1.0 (ref) & $<0.001$ & 10.9 & 0.0 (ref) & $<0.001$ \\
\hline & $10-19$ & 36,785 & $4 \times 10^{-3}\left(2 \times 10^{-3}-9 \times 10^{-3}\right)$ & & 15.3 & $5.8(1.4-10.2)$ & \\
\hline & $20-29$ & 947 & $1 \times 10^{-4}\left(4 \times 10^{-5}-2 \times 10^{-4}\right)$ & & 25.3 & $14.8(10.3-19.4)$ & \\
\hline & $30-39$ & 318 & $3 \times 10^{-5}\left(1 \times 10^{-5}-7 \times 10^{-5}\right)$ & & 23.4 & $17.1(12.8-21.4)$ & \\
\hline & $40-49$ & 170 & $7 \times 10^{-6}\left(2 \times 10^{-6}-2 \times 10^{-5}\right)$ & & 21.8 & $20.3(14.5-26.0)$ & \\
\hline & $50-70$ & 145 & $2 \times 10^{-6}\left(4 \times 10^{-7}-1 \times 10^{-5}\right)$ & & 20.5 & $28.2(21.3-35.0)$ & \\
\hline \multirow[t]{2}{*}{ Birthplace } & Keneba & 1,723 & 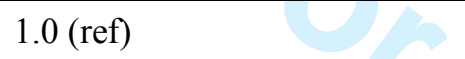 & 0.6 & 20.6 & 0.0 (ref) & 0.4 \\
\hline & Manduar & 5,704 & $1.2(0.6-2.2)$ & +8 & 18.9 & $-1.2(-3.9-1.4)$ & \\
\hline \multirow[t]{2}{*}{ Maternal HBsAg } & Negative & 3,607 & 1.0 (ref) & $<0.001$ & 17.6 & 0.0 (ref) & 0.005 \\
\hline & Positive & 21,499 & $4.7(2.0-11.1)$ & & 22.5 & $4.0(1.2-6.8)$ & \\
\hline
\end{tabular}

${ }^{1}$ Mean difference, $\mathrm{p}$-value and 95\% CI estimated using a linear mixed models to account for repeated measurements within participants.

${ }^{2}$ Test for linear trend.

${ }^{3}$ Mean difference adjusted for sex, current age, age at study entry and birthplace. 
Supplementary Figure 1. Age-specific prevalence of HBeAg in chronic HBV carriers at baseline $(n=405)$

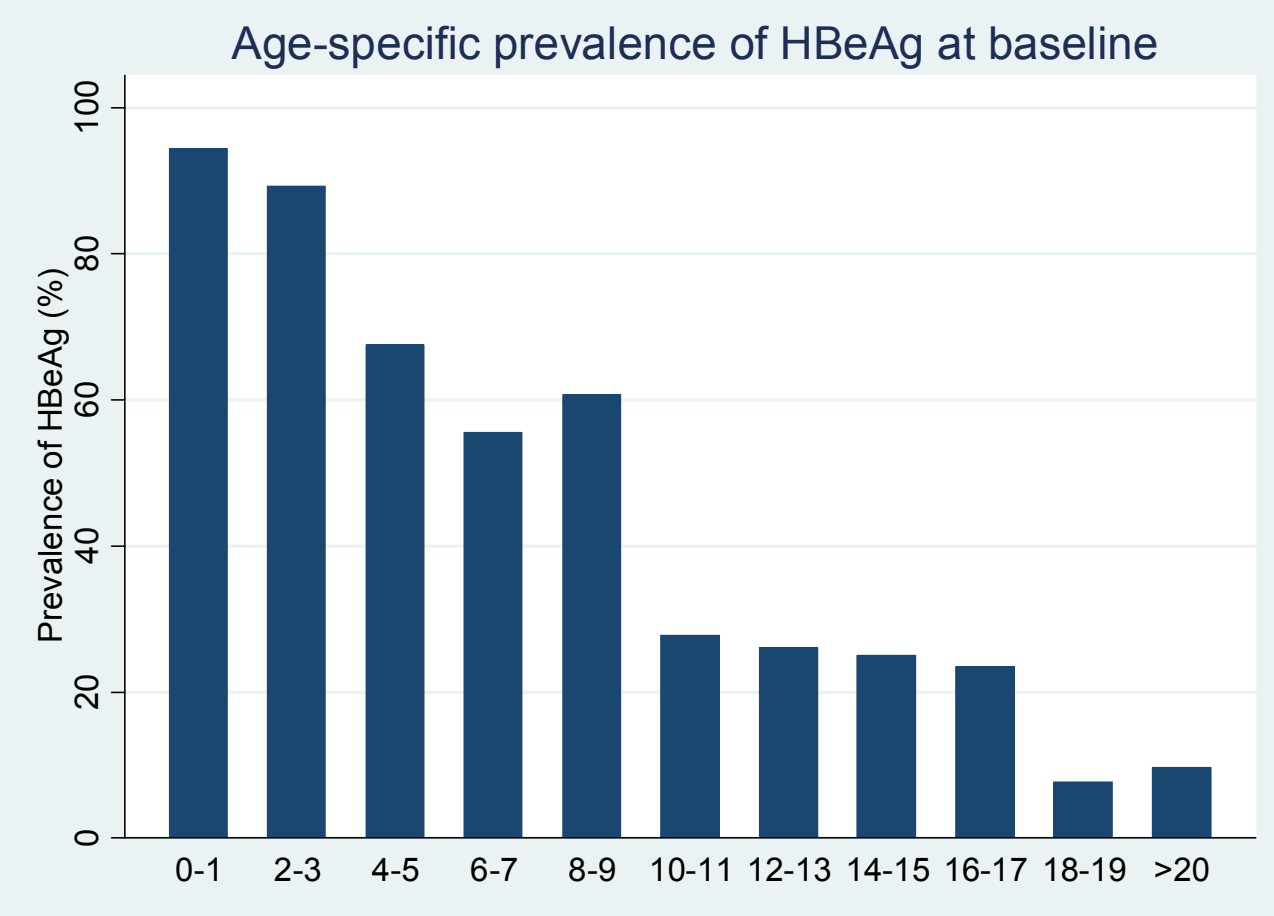




\section{Supplementary Figure 2. Proportion of chronic HBV carriers who cleared HBeAg (A) and} HBsAg (B) as a function of age and according to maternal HBsAg positivity*

* The number at risk is smaller at 5 years than at 15 years in supplementary figure 2-B because the
median age of recruitment was 10.8 years.

Supplementary Figure 2-A

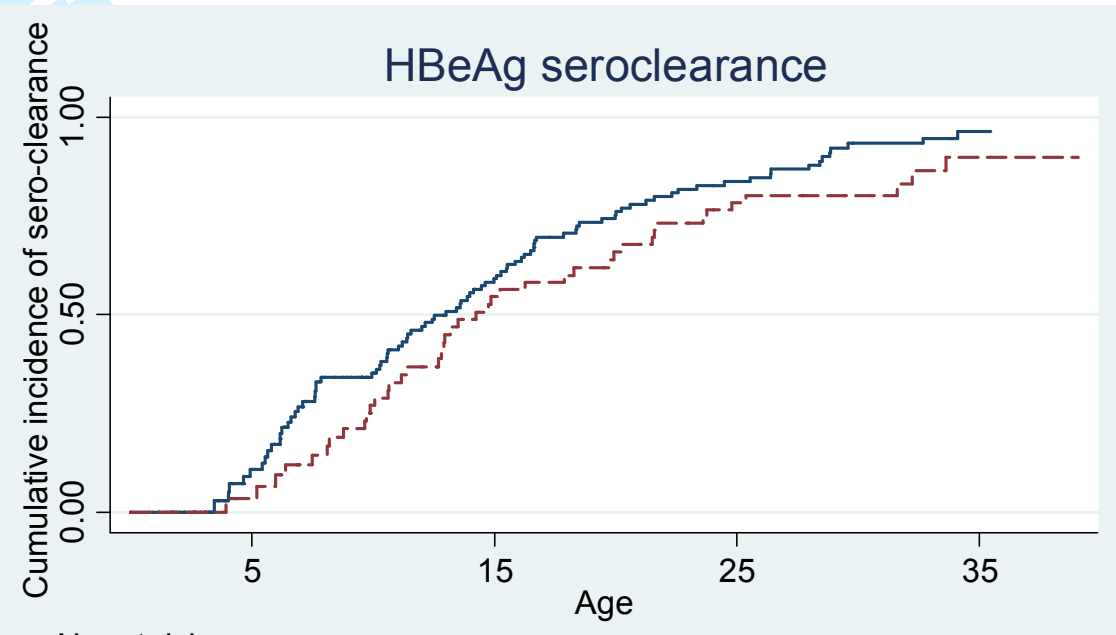

No. at risk Negative mother 54

Positive mother 31

46

16

12

2

\begin{tabular}{c|c|} 
Maternal HBsAg \\
Log rank $p=0.1 \quad$ negative ---- positive \\
\hline
\end{tabular} 


\section{Supplementary Figure 2-B}

1
2
3
4
5
6
7
8
9
10
11
12
13
14
15
16
17
18
19
20
21
22
23
24
25
26
27
28
29
30
31
32
33
34
35
36
37
38
39
40
41
42
43
44
54
55
56
50
50
50
50

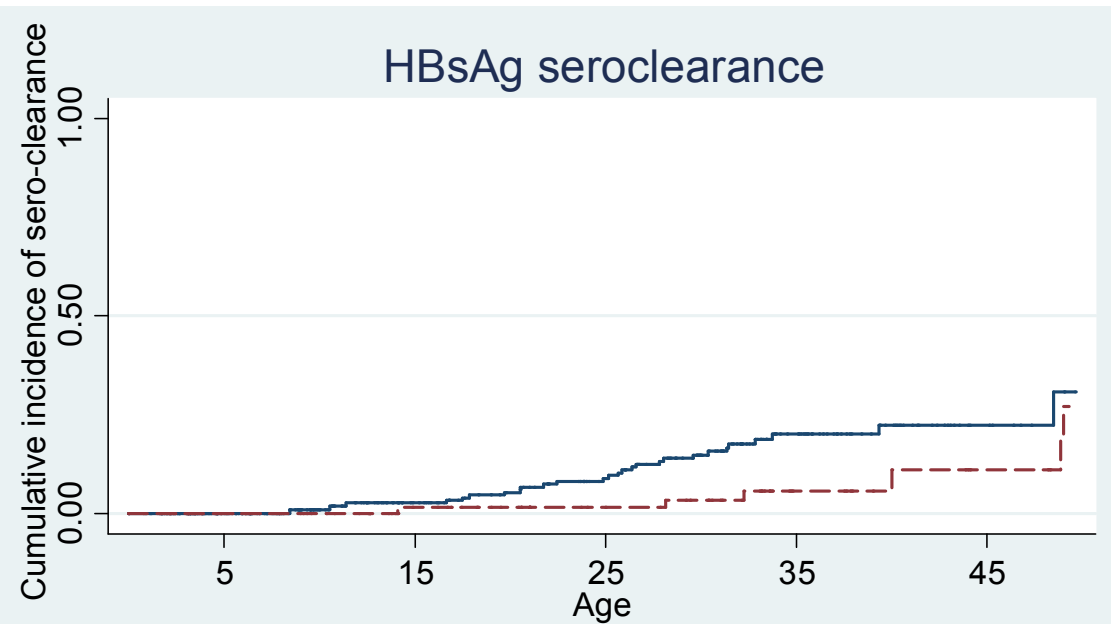

No. at risk

$\begin{array}{llllll}\text { Negative mother } & 64 & 138 & 127 & 57 & 14\end{array}$

Positive mother 42

61

30

13

Log rank $p=0.07$

Maternal HBsAg

negative -- - - positive 
Supplementary Figure 3. Changes in phase of natural history between baseline $(n=405)$ and 2012-2013 liver assessment $(n=301)$

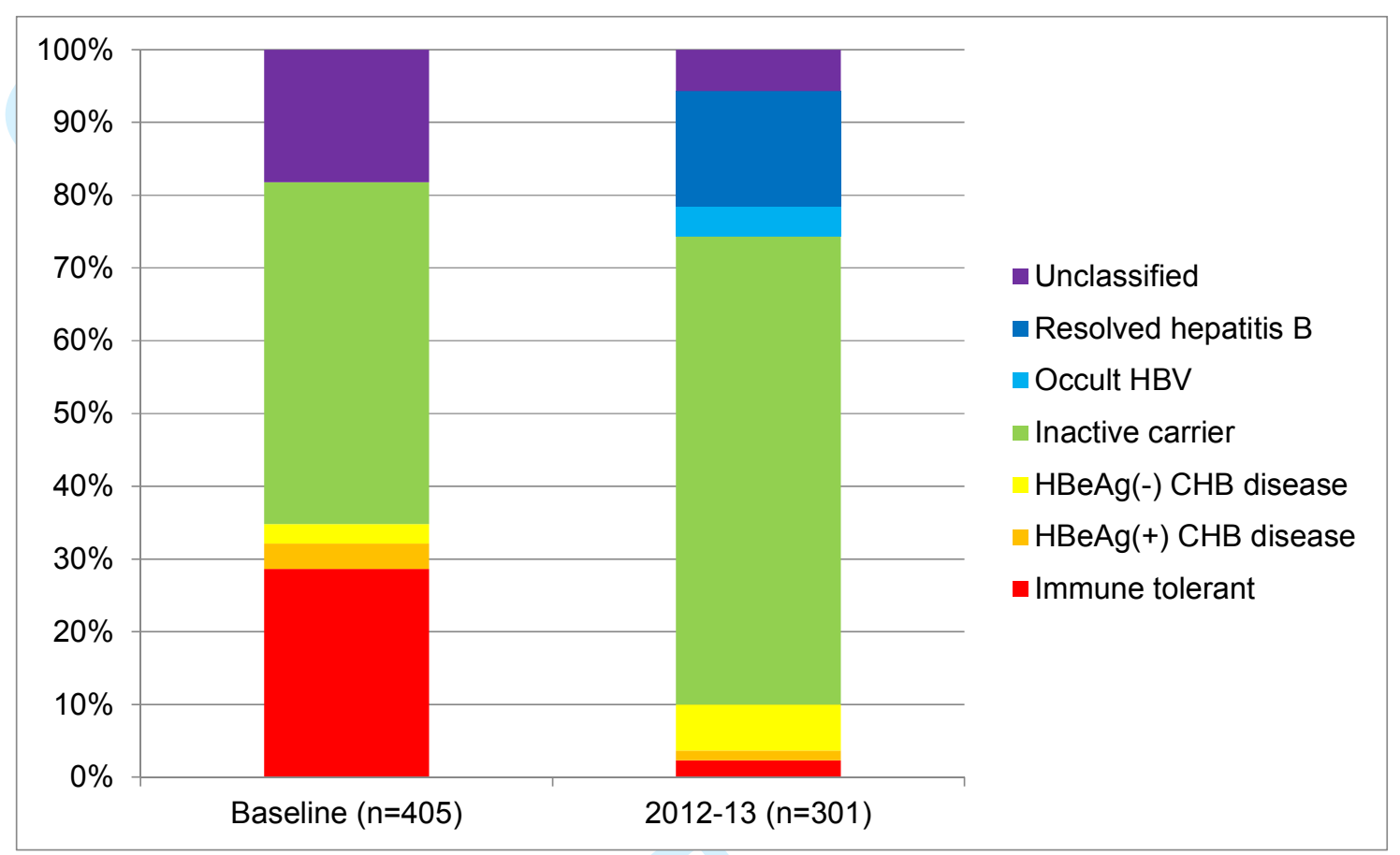

